\title{
Born to Care: Conceptualizing Conscience to Foster Moral Education and Action
}

\author{
Robert Wade Kenny \\ Department of Communication Studies, Mount Saint Vincent University, Halifax, Canada \\ Email:wade.kenny@msvu.ca, doctorwadekenny@hotmail.com
}

Received 4 January 2016; accepted 27 January 2016; published 30 January 2016

Copyright (C) 2016 by author and Scientific Research Publishing Inc.

This work is licensed under the Creative Commons Attribution International License (CC BY).

http://creativecommons.org/licenses/by/4.0/

(c) (i) Open Access

\section{Abstract \\ This essay is predicated on the belief that ethics educators should guide students toward a proper understanding of conscience. To that end, conscience and the qualities that are intertwined with it and make it possible are set forth.}

\section{Keywords}

Selfhood, Ontological, Moral Turbulence, Inter-Relational, Authentic Justice, Reflexivity, Mindfulness, Will, Situated and Habituated Conscience, Dead Conscience, Authentic Guilt, Authentic Shame, Reparation, Resoluteness, Creative Imagination

\section{Introduction}

"Without conscience there can be no moral actor."

\section{Philip Selznick ${ }^{1}$}

Never has there been such a focus on ethics education. Entire libraries and institutes are devoted to ethics. Specialty departments exist to manage bioethics, legal ethics, and business ethics. Research activity is compelled to pass scrutiny before ethical review boards. Lawyers are brought under ethical review; and scholars debate the minutiae of ethical situations, both real and imagined. So much ado about ethics yet ethics remains confounded in both its formalization and its practice within a cultural context where "...all the primary relationships in our society, those between employers and employees, between lawyers and clients, between doctors and patients, between universities and students are being stripped of any moral understanding other than that of market exchange" (Bellah, 2006: p. 402).

A profound statement, yet even it falls short of the mark, as the contemporary crisis in ethics is driven by

${ }^{1}$ (Selznick, 1992: p. 179). 
more than a pathological profit drive. Beneath and beyond that drive there is a more general unwillingness or failure of persons to self-regulate their conduct with regard to others, what Van Wyck Brooks typified as "insane individualism" (Pells, 1998: p. 7). This is a phenomenon that we may notice when we look at contemporary interpersonal relationships, the ever-escalating divorce rate being a significant example. But also, on the national scale, we saw it in the corruption of Wall Street, which led to the collapse of the banking system in 2008. And on the international scene, this is the most notable in the stories of abuse and cover-up among the Catholic clergy. And then of course we have our wars. Now, among the professional cases at least, it is unlikely that the people who commit such injustices have no training in ethics. Wall Street is well-populated by lawyers who are obliged to take ethics courses. Catholic clergy devote lifetimes studying and teaching on the ethical life. Military schools train students in the ethics of warfare and many soldiers are raised within a religious faith that is, itself, laden with ethical principles. Perhaps people can answer questions about the ethical life on multiple-choice tests. Perhaps they can argue interminably about its essence. Nevertheless, it remains a problem for them to "guide their desires and actions by principal" (Aristotle, 1996: NE, 1, 3, 7). And so it may be time to diminish the focus on morality as a rhetorical problem and to recognize that "an adequate moral theory must be based upon, and remain faithful to, the facts of moral experience” (Mandelbaum, 1955: p. 35).

This challenge to address the facts of moral experience has grown more complex in the last 100 years, in that the scale of things for which a person is capable of feeling accountable has broken from the scale of things that people can relate to as personal wrongdoings, so that our "imagination is unable to grasp the effect of that (destruction) which we are producing... (a destruction that is) infinitely far outside the sphere of those actions which we can visualize and towards which we can take an emotional position” (Anders \& Eatherly, 1989: p. 12). Are the rivers being poisoned because I use a shampoo? Will sea levels rise 20 feet because I drive an automobile? Are people being killed on a daily basis because of my taxes? I am told that the answer to these questions is a qualified yes, but it remains impossible to fathom because of the space between my isolated personal behavior and the global consequence that arises when millions of others do the same. I simply cannot imagine 1 billion plastic cups, 10,000 gallons of soap scum, or 60,000 cubic feet of carbon monoxide-the impact of destructive scale has, that is to say, lessened, rather than increased the individual's sense of obligation; so that the expression "I was just following orders" has been amended to "this problem surpasses both my ability to influence it and my ability to feel responsible for it”. Fukishima, Bhopal, the Gulf oil spill, global warming, antibiotic over-usage, even the methane leak in California that continues to spew as I write this line-all these and many more are catastrophic beyond measure. They push habitability on this planet to the breaking point. Moreover, their destructive potential as a whole is exponentially greater than any single one. But the primary consequence has not been an increase in urgency. Rather, as Günther Anders, the thinker who makes the point I elaborate here (see above citation) $)^{2}$ suggests: this problem of scale causes a schizoid process in people, a variation of the well-known psychic defense mechanism referred to as splitting (Grotstein, 1985). Where it occurs the individual brackets all public responsibility as something apart from those things for which personal responsibility is demanded. "Those are corporate issues”, one says, "or they are the concerns of government”. And, of course, when everyone regards a matter as a public responsibility, so conceived, no one feels responsible at all!

Where responsibility is felt, but unanchored to an understanding of the inner qualities that move one toward the ethical, moral turbulence ${ }^{3}$, a crisis for thinking and choosing in a whirlpool of circumstance arises. However, torment is not an adequate solution to a moral crisis. Something more is required.

Evidence has shown that the debating of moral problems is not enough (Kilpatrick, 1992: pp. 89-90). Nor is it sufficient to focus on "the formation of character in young people... a different task from, and a prior task to, the discussion of the great difficult ethical controversies of the day" (Bennett, 1993: p. 13). Both these tasks are well-considered and necessary. However, at the university level, the initial task demanded of the ethics instructor is the guidance of students toward their own considered understanding of who they are and what potential for goodness exists within them. They must be acquainted, that is to say, with those characteristics specific to

\footnotetext{
${ }^{2}$ Anders, who once was married to Hannah Arendt, makes his point in written correspondence with Claude Eatherly, the weather-scout pilot for the Hiroshima bomb. Note that the margins of guilt taken up by Eatherly as a Hiroshima participant fell narrowly on his own shoulders, as others involved did not experience the horror of the event. Indeed, he wrote to Anthers that, "Society simply cannot accept the fact of my guilt without at the same time recognizing its own far deeper guilt” (Anders \& Eatherly, 1989: p. 36). His psychiatrists at the VA referred to his guilt as a "Hiroshima complex", thus turning his conscience into a psychiatric aberration. Though a mountain of self-condemnation fell on Eatherly, others were able to steer clear of shame and the burden of conscience.

${ }^{3}$ I use the expression psychic turbulence when referring to a generally confounded state of inner life (thoughts, feelings, memories, plans, expectations, and so forth) that exists in a person who lacks a framework for making sense of the inner and the outer world. Moral turbulence is a subcategory of that more general state.
} 
People, resources (potentialities) that make them capable of moral education and ethical advance. For only if they come to terms with their own ontological potential to be ethical selves - only if they both recognize and understand that potential—will they be motivated to seek an understanding of the ethical as a deeper understanding of themselves.

People have this ontological potential. They possess it, allegorically, in the manner that they possess their eyes. But, just as eyes will never develop if a person fails to open them, so will the ethical vision be confounded if it is not understood and used, leaving people diminished in their capacity to experience the fullness of life. Students in an ethics course must therefore learn more than how to convince themselves or others that a point of view is valid-that is no more than sophistry. And they certainly should not be there to learn a collection of rules. They should instead, during their study of ethics, be guided toward a discovery of the moral potential that already exists within them simply because they are human; so that they might learn how to cultivate that potential within themselves. As Lloyd Averill suggests:

The question, “Who am I?”... is existentially prior to, “What shall I do?” and must be discussed at the heart of the educational effort if the college is to impart a significant moral dimension to student thinking. A college can contribute to "moral clarity" in student thinking, Dr. Averill maintains, only if it is prepared to deal openly and honestly with the questions men ask about themselves. "When that which is most human is evaded and avoided," he warns, "moral clarity is subverted” (Ratterman, 1971: p. 244).

Thus, it should be a goal of ethical study to guide students toward a deeper understanding of who they are and what they have a potential to become, so that they may take up the challenging task of coming to terms with the good.

At the center of that deeper understanding is the light of conscience, the focus of this essay.

\section{On the Lived Experience of Conscience: Allegory as Explanation}

At various times, particularly in contemplative moments, people tend to experience their lives in story structure. ${ }^{4}$ When this occurs, they contemplate the past as a structured narrative that gives way to the present, and they anticipate the future as a tale that will complete the full trajectory. ${ }^{5}$ By way of illustration, the boy in the midst of piano practice sighs, pauses for a glass of water, thinks back over his years of dedication to the keyboard, and imagines the applause attendant upon his recital, affirming this (short story) narrative as a triumph of the self through having anticipated and made "all the right choices."

Now, those who actually write stories choose events very carefully, and they are quite cautious what they allow their characters to do in the tale, because they know that certain characters must be portrayed up to a certain standard if they are to go where the narrative is taking them. No writer, for example, would write a children's story about a piano student winning the piano competition by breaking the fingers of other children instead of practicing, for such a violent action would make the boy an illegitimate character on the pathway to success. ${ }^{6}$ Similarly, while there are many children who have practiced piano, and many who have not, few have attempted to solve the challenge of the recital with a hammer and a pair of pliers.

Much in the manner of authors contemplating characters, then, individuals contemplate their existence. And, while doing so, conscience supervises how they choose among the immediate options for the sake of the narrative-unfolding of the past and the yet-to-be that they regard as the meaning of their lives. ${ }^{7}$

\section{Conscience as the Ontological Foundation of Goodness}

Human beings are born with a range of material and psychic potential, and they have the ability to develop that

\footnotetext{
${ }^{4}$ This makes it possible for them to tell life stories ranging from a description of what happened yesterday to a complete autobiography.

${ }^{5}$ For a more detailed explanation, with illustrative case study (see Kenny, 2001).

${ }^{6}$ Such tales can be told, but only in the ironic form (Kenny, 2003: pp. 663-664).

${ }^{7}$ Of course, there are many times when people are not in such a contemplative state, but this is not always a recipe for disaster. Not all moral choices are momentous-life-changing challenges may not arise; and, on the occasions that they do, great moral failures still might not occur, acting agents having successfully responded to a crisis merely by virtue of thoughtless habit or lucky choice. Nevertheless, there will be occasions on which they say proactively "If I do (or don't do) this, I will become this, and my story will evolve thus", and there will be occasions upon which they say retrospectively "I have done (or have not done) this, and now I have become this, and my story will evolve thus." In many cases, the contemplated act does not amount to a fated determination of the totality of a life story or of a life. But, in a more general and contemplative sense, a narrative way of thinking is a strong allegory for both the positive enthusiasm and the anxiety of conscience.
} 
potential as they mature. The psychic part of that equipment is sometimes referred to as ontological (Heidegger, 1962: p. 288). Thus, it includes competencies such as judgment, anticipation, memory, and expectation-manners of relating to the world, "built in" structures that interact with the social circumstances to form an articulated person. Conscience is such a structure-it is the one that takes up the task of managing one's responsibility to the world.

How is it that a living creature can exist with a conscience — can bear a sense of responsibility with respect to the past and the future and also believe that it is burdened to achieve proper conduct, particularly in a world where irrationality and randomness play such a critical role in the outcome of many situations? An answer is given from as far back as Socrates, who argued that a person's moral vision is a divine endowment, another way that human consciousness can participate in eternal principles, a parallel to their ability to contemplate mathematical truths, such as the Pythagorean theorem, something no other creature can do (Russell, 1945: p. 37). ${ }^{8}$ A more contemporary explanation argues that structures of co-obligation and justice evolved in human beings as a necessary condition for collective life (e.g., Voland, 2014; Turner \& Stets, 2005). Certainly we know that, whatever the source of the mystery of conscience, the fact of its existence is self-evident in our emotional and reasoning experiences, if only by the way it haunts or troubles us. As to its source, in both the classical argument and the evolutionary one, a capacity to judge the self and the self's action with respect to some broader notion of the good is recognized as a naturally occurring potential in people, in part because it is so commonly observed in others and intuitively recognized in the self. Conscience is, in this sense, a first principle because it is "rooted in man's essential being" (Weisskopf, 1959: p. 218) and we know it is there because we experience it as there through our ongoing struggles to satisfy or endure it.

To some extent, there is a danger associated with thinking that conscience is a gift from divine light, however, and that is the misbegotten idea that conscience, presumed-perfect in its origin, is also perfect in its calculability (its knowledge of what should be done) and always justified in its advocacies and its condemnations. This is a way of thinking about conscience that only the religious will accept, and not all of them! In an ethics class that is not grounded in religious principle, conscience must be characterized in terms of a broader framework-as a natural capacity that has 1) biological, 2) social, and 3) synthetic characteristics. Conscience's biological characteristics are associated with the essential requirements for being an animal that lives in collectives (such as the sense that one should care for others in a manner that increases the closer those others are in blood relation, proximity, and service). Its social characteristics are derived from the practices specific to the particular society (such as the sense, in some communities, that one should give gifts on Christmas day). And the synthetic qualities of conscience arise from the considered resolution of conflicts between and within conscience's biological and social demands. Conscience is not, that is to say God's adjudicator for His perfect will in this world-not even Catholic theologians and philosophers believe that. ${ }^{9}$ Rather it is rooted in experience and mutates over time, in keeping with circumstance (Scheler, 1973: pp. 317-328). This is why there are notions of the erroneous conscience, the distorted conscience, the sick conscience, and the high or noble conscience. Whatever state the conscience exists as, however, it will continue to act as a personal censor of both action and thought-unless it is dormant or dead. For these reasons, let us not imagine conscience as an angel or an abacus, infallible in its very nature-let us think of it instead as a plant that must be cultivated and grown across a long period of time, in order for it to blossom, and in order to gainsay the brilliance of the bloom. ${ }^{10}$

That authentic conscience is the very foundation for achieving and maintaining selfhood seems absurd. Certainly we know who we are even without exercising the conscience. Yet, is it possible that any self known before the awakening of conscience, is an illusion? This is what Heidegger believed. He believed that it was possible to learn and play the allotted social role with such depth and conviction that one could lose all sense of one's authentic self, which remained undisclosed:

With Dasein's lostness in the "they", that factical potential-for-Being which is closest to it (the tasks, rules, and standards, the urgency and extent, of concernful and solicitous Being-in-the-world) has already been

\footnotetext{
${ }^{8}$ Of course, a person who learns nothing about numbers will have very limited mathematical vision or imagination—just so with conscience and moral agency in general.

${ }^{9}$ E.g., "No decision...will be made with certitude. There are no guarantees: neither God, nor Christ, nor life itself will act as an insurance company certifying a happy outcome-giving warrant that the decision made is the best possible. Decisions are an experiment in relationships.” (Birmingham, 1971: p. 292)

${ }^{10}$ In any case, this is not an essay intended to resolve the challenges associated with various interpretations of the origins of conscience-its goals are much more pragmatic, as described in the opening section of the work.
} 
decided upon. The "they" has always kept Dasein from taking hold of these possibilities of Being. The "they" even hides the manner in which it has tacitly relieved Dasein of the burden of explicitly choosing these possibilities. It remains indefinite who has "really" done the choosing. So Dasein makes no choices, gets carried along by the nobody, and thus ensnares itself in inauthenticity. This process can be reversed only if Dasein specifically brings itself back to itself from its lostness in the "they". But this bringing-back must have that kind of being by the neglect of which Dasein has lost itself in inauthenticity. When Dasein thus brings itself back [Das Sichzuriickholen] from the "they", the they-self is modified in an existential manner so that it becomes authentic Being-one's-self. This must be accomplished by making up for not choosing [Nachholen einer Wahl]. But "making up" for not choosing signifies choosing to make this choice-deciding for a potentiality-for-Being, and making this decision from one's own self. In choosing to make this choice, Dasein makes possible, first and foremost, its authentic potentiality-for-Being (Heidegger, 1962: p. 312).

Given that concern, and with a view toward uncovering the nature of this fundamental part of being human, so that students have a foundation upon which to form their choices, the following general, proactive, and retrospective qualities of conscience are set forth.

\section{Conscience as Selfhood and Self-Determination}

In order for conscience to evaluate one's role in an action scenario, a person must have a refined sense of identity; for identity, which sets the boundary between those acts an individual claims proudly ("This act is part of who I am!”) and those acts that are out of the question, is the North Star toward which all moral action steers. This idea is at the very heart of Aristotelian ethics, which claims that the goal of all ethical action is to remain "true to yourself". The word used by Aristotle is eudaimon, a compound word from Greek that means "proper" (eu) "spirit" (daimon). Early Greeks believed that the individual could be possessed by a variety of spirits (dai$m o n)^{11}$ but it was Aristotle who distinctly claimed that there could be a spirit (let us say self) that is proper for a given person. The idea has followed the history of philosophy quite closely, so that we can see it even in the distinctive vocabulary of Martin Buber, who calls it, "essence-by this I mean that for which a person is peculiarly intended, what he is called to become" (p. 90). It is also popular in folk expressions as well, when, for example, we say, "I'm sorry, I'm not feeling myself today." And it is because we have this proper sense of being, and of identity, that we are able to prioritize those acts of "a self that is striving for...something that would enable one to say to oneself, 'I have made myself more significant in my own eye’” (Henry, 1971: p. 13).

Sometimes eudaimon is translated as happiness, but it is not a good idea to suggest this to students, for they naturally think happiness is self-evident (i.e., they think it means anything that results in pleasure or gleefulness is good); and, of course, there are many forms of happiness that Aristotle did not intend to suggest. Like Socrates, for example, Aristotle did not mean to suggest that a well-satisfied pedophile achieves eudaimon in his abusive and patently disordered happiness. ${ }^{12}$ Indeed, it turns out, as mentioned earlier, that the etymological meaning of eudaimon (i.e., proper spirit) is closer to the philosophical meaning; but we could also think of joy as the goal of the ethical life, if we understood joy to mean responsible happiness; for, thinking of it this way, we set the ethical goal apart from thoughtless glee, narcissistic self-involvement, and the like. Thus, the two translations are connected, for a proper self is one that takes responsible account of its relation to the world and experiences that proper relation as joy.

The authentic self then, whatever its mysterious origin and the fullness of its nature, is immediately recognized in living, once we cease to allow the cultural scripts for conduct and happiness to stand in for our own concerned attitude toward what must be done. When authentic selfhood arises, we know who we are, where we are, and what we stand for (even if the fact of it makes us miserable); or, at the very least, we are committed to

\footnotetext{
${ }^{11}$ In our own time, a vestige of this notion remains with us as demonic possession.

${ }^{12}$ Socrates makes the point in Plato's Gorgias:

SOC: Callicles, I would have you consider how you would reply if consequences are pressed upon you, especially if in the last resort you are asked, whether the life of a catamite is not terrible, foul, miserable? Or would you venture to say, that they too are happy, if they only get enough of what they want?

CAL: Are you not ashamed, Socrates, of introducing such topics into the argument?

SOC: Well, my fine friend, but am I the introducer of these topics, or he who says without any qualification that all who feel pleasure in whatever manner are happy, and who admits of no distinction between good and bad pleasures? And I would still ask whether you say that pleasure and good are the same, or whether there is some pleasure which is not a good? (Plato, 1963: e494).
} 
finding the answer to these questions. This commitment to the authentic self thereafter plays an instrumental role in the governance of our lives; so that we can feel joy even in the midst of tragedy, if we see in whatever loss we face a truth far more important that nevertheless endures. Indeed, the more thoroughly we know the self, the greater our power to act sincerely with respect to it:

Those are great moments of existence when a man discovers his essence or rediscovers it on a higher plane; when he decides and decides anew to become what he is and, as one who is becoming this, to establish a genuine relation to the world; when he heroically maintains his discovery and his decision against his everyday consciousness and against his unconscious (Buber, 1971: p. 95).

The self is influenced by a variety of forces, however: for example fear, desire, and greed. Therefore, in order for it to make considered choices, it must be partnered with an entity that can counter these impulses and keep the self on a steady course toward its best possibilities. Both philosophy and tradition give the name conscience to the primary entity that takes up this managerial role.

Conscience is envisioned in this characterization as a being separate from (although infinitely close to) the self - a being that manages all assessments of the self's choices and behaviors; then reports back to the self with regard to these assessments. This report to the self can come in the form of guilt and shame, or it can come in the form of pride and joy, depending on whether conscience approves or disapproves of what the self has done. Sometimes it sends its message in dreams, sometimes in moods, and sometimes it is possible to hear accusing words within one's own mind. In any case, the internal "presence" of these two beings ${ }^{13}$ of the self and the conscience, traces back to the Socratic dialogue Phaedrus and is what Hannah Arendt calls "the two in one" (Arendt, 1978: p. 64).

The idea of conscience as an internal parental guardian (but, again, only in an allegorical sense) is long-recognized in Western thinking. For example, the first century Greeks used the term $\Sigma v v \varepsilon i \delta \eta \sigma i s$ (pronounced synethesis) to characterize conscience as an internal witness to one's own improper acts-an adjudicative force that, in order to balance the universe, brings pain when actions are determined unjust (Turro, 1971: p. 5):

For every self has for its birth-fellow and house-mate a monitor ... (that) accuses and puts the self to shame, and again as judge, he instructs, admonishes and exhorts it to change its ways. And if he has the strength to persuade it, he rejoices and makes peace. But if he cannot, he makes war to the bitter end, never leaving it alone by day or night, but plying it with stabs and deadly wounds until he breaks the thread of its miserable and ill-starred life (Philo, 1937: p. 59).

And it is interesting, given a comment of this sort 2000 years ago, the degree to which modern therapy is organized around a notion of a self at dis-ease, an improper self, or, to coin a term, dysdaimon. Writers from Freud to John Bradshaw have extensively treated the relation between this improper self and human misery; and many have regarded the dynamic relationship between conscience and the self to be at the root of these troubles. Thus, a variety of prominent therapists have argued that coming to a state of emotional well-being involves the force of conscience establishing a proper relationship between one's actions and one's identity. Such therapists believe that conscience reveals the self by generating the pain (Kierkegaard writes "the despair") that is attendant upon the patient's falsehoods. "Consequently, to be able to despair is an infinite advantage" (Kierkegaard, 1978: p. 15), because the emerging state of despair usually signals that one still knows, at some level, who one truly is. ${ }^{14}$

It would be a mistake to imagine conscience as a punitive mechanism in the human psyche, however. Rather, conscience is inextricably intertwined with the relationship between freedom, responsibility, and selfhood in such a way that, should we activate it in a timely manner, conscience may elevate our sense of self, our sense of healthy pride, and our ability to relate meaningfully with those people who share our lives. Thus, its primary role is to facilitate our relation to the expression of selfhood, by bringing us the joy of self-affirmation (eudaimon) for our authentic action and misery (dysdaimon) for our falsehoods. In this way, a proper relationship between conscience and the self occurs when one meaningfully copes with the ambiguities and ambivalences of

\footnotetext{
${ }^{13}$ Of course, the status of these "beings", the self and the conscience, is abstract, as is the case for all mental processes. Internal states are named in the manner we name things that we can see in order to make sense of inner life, which does not have a material form that is bounded and visible. While there is always a debate with respect to the nature of each of these "inner beings", it would make no sense to abandon speaking in this way - that would amount to the end of philosophy, psychology, and some of the other humanities as well!

${ }^{14}$ Kierkegaard names not knowing one has a self as a type of despair, but he admits that this sort of being lost is radically different from losing a known self or feeling the impossibility of holding onto or becoming a clearly-visioned self.
} 
circumstances within and outside the self and others. While this may sound like an oppositional system that creates only struggle, the dynamic is much more complex, such that the authentic self emerges not only through division from, but also merger with, others. Indeed, authenticity "is not the enemy of demands that emanate from beyond the self; it supposes such demands” (Taylor, 2003: p. 41). This is to say we find the completion of ourselves in the relationships we make with the world and the people around us-relationships that will be discussed in the next two sections of this essay, which deal with inter-relationality and justice.

\section{Conscience as Inter-Relational}

Whenever we speak of conscience as a faculty that is "self-related", we run the risk of appealing to narcissistic conceptions of selfhood. That would be a serious error for although "authenticity arises because every person is a distinct biological and historical unity... (he or she is also) at the same time inescapably a part of animal and social life.” (Selznick, 1992: p. 70) Thus, rather than advance any notion of an isolated or isolatable self, it is critically important to keep in mind that the self "is not simply a self-contained system, and so... personal fulfillment cannot focus upon oneself, as if selfhood were best taken care of in a literal and direct manner” (Anton, 2001: p. 148). Conscience, we should say in light of this, also has an inter-relational character.

Like hearts, lungs, kidneys, and brains, which cannot survive independent of each other, human beings are embodied in such a way that they cannot survive in isolation from what is around them. Thus, people do not arrive in the world with the ability to generate their own oxygen, their own food, or even their own ability to reproduce, for evolution has not developed them as self-sufficient, autonomous creatures. In this sense, at the very heart of their existence, they are parts and not wholes, obliged to find completeness in the world around them (which they co-manage), a world that possesses the resources they lack. Much as an automobile, completely assembled and functioning properly, would yet be absurd without a fuel source and a road, just so is human existence impossible without an environment and other human beings. Moreover, much of a person's unique completion will be determined by the particularities of that environment (e.g., language, food, customs). To be sure, an individually existing human being "is always touching something it is not, always. Never am I isolated or not in various forms of contact” (Anton, 2001: p. 33).

Because the surrounding world inter-penetrates each of us (e.g., oxygen enters our lungs feeding us, and carbon dioxide exits our lungs feeding plants), human beings can be thought of as environmental, inter-worldly creatures. At the most elementary level, they make and remake themselves from things that are outside them- the air, the water, plants, and animals—-possessing the tools of inter-worldliness (i.e., lungs, nose, mouth, teeth, etc.) in order to do so. But human beings do not rely solely upon the world to survive- they also rely upon each other. Humans, that is to say, are not only inter-worldly but also inter-human, existing in such a way that they achieve completeness only with others of their kind with whom they hunt, reproduce, build, farm, shop, plan, speak, think, and so forth. Inter-worldliness and inter-humanness are, then, the two forms of inter-relationality that humans do and must possess. Sometimes characterized by philosophers as types of openness towards the world and its others (as openness towards being), inter-relationality is a necessary condition for human existence.

The idea of inter-humanness was a focus in the writing of Martin Buber who used it to establish his I/Thou conception of inter-relationality. And, indeed, it would be a fine thing if inter-relationality brought only benefit to the world and humankind. But this is not the case. Torture, for example, is an art made possible by inter-humanness, as are murder, rape, theft, and war. Neither does the fact that we are inter-worldly guarantee that we will be environmental caretakers. Automotive pollution, deforestation, fracking, oil spills, and nuclear disasters are also the products of the inter-relationality of humankind. Thus, inter-worldliness and inter-humanness move definitively in the direction of caretaking only in the presence of an activated conscience that manages and thereby ennobles inter-relationality. Concern for other things and other people are, that is to say, instrumental in ethics because "no ethical system can really be one unless it is anchored in — not merely considers— the other" (Henry, 1973: p. 110).

Understanding that conscience directs the inter-relational and inter-human aspects of being a person helps students grasp the idea that conscience is more than a burdensome psychic experience that inhibits their freedom to be a self. Rather, by allowing them to recognize that their selfhood is intertwined with the world as the way they become the individuals who nurture and protect the things and people that they value- the idea that "I care for myself by caring for others," becomes self-evident. Moreover, knowing that conscience guides inter-relationality toward caretaking also helps students understand that conscience plays a fundamental role in how others will treat 
them. It thus moves them in the direction of valuing conscience, rather than narcissistically imagining it as a force that attacks them for enjoying their pleasures. Through a grasp of inter-humanness, students can also see how conscience plays a role in preserving all forms of interpersonal relation up to and including civic duty. Thus it acts as a first step in overcoming radical individualism, the fallacy that our lives are as separate from each other as our bodies and that human freedom involves acting for the sake of that individual body rather than for the sake of the whole self-the whole self, which includes all of one's others as well.

But what is the mechanism that allows conscience to assess the balance between self and the world? The philosophers have called it justice, which can be conceived as a disposition that stands alongside conscience, reporting to it, or as an essential aspect of conscience itself.

\section{Conscience and Authentic Justice}

Earlier in this essay, it was made clear that the task of conscience is to manage the relationship between the self and the things that the self does. What remains to be described is the internal mechanism that triggers conscience to go about its managerial duties responsibly. That internal mechanism is justice.

The endowment of justice, much like the gift of conscience can be conceived in terms of heavenly or earthly roots. Thus, Thomas Aquinas tells us that the human being experiences its natural state as "participatio legis aeterna in rationali creatura", which effectively means that people were designed to experience directly from within themselves the truth of eternal law, because "the light of natural reason, whereby we discern what is good and what is evil...is nothing else than an imprint on us of the divine light” (Aquinas, 1945: p. 750). ${ }^{15}$ Correlatively, justice can be characterized as a balancing mechanism that evolved in order to facilitate group harmony in a group species. In either case, as was said of conscience, the self-evident presence of justice in our practices indicates that justice exists, irrespective of the nature of its origins. ${ }^{16}$

We have already suggested that people are inter-relational (i.e., both inter-worldly and inter-human); and, in that characterization, we made clear that both care for one's world and care for one's others are necessary conditions for human existence because they are indirect ways of caring for self. Indeed, when Cicero writes that, "all virtuous men love Justice and Equity, for what they are in themselves" (Cicero, 1841: p. 60), he points us in the direction of this very important consideration.

The giver of care is also a beneficiary, profiting simply from the accomplishment of the act, and testimony from the concentration camps is unanimous on this point. "Probably this is the best way to retain one's humanity in the camps", Ratushinskya remarks, "to care more about another's pain than about your own. We were not seeking to perform heroic acts: if anything these were acts of self-preservation” (Todorov, 1996: p. 88 [abridged]).

Care is, in this sense, a maximum expression of the inter-personal commitment of authentic conscience, while justice represents the minimal.

But what can it mean to love justice? It means that those who do so have found truth, peace, and joy at those moments when conscience brings justice and the self together, confirming to the authentic self that it has been just, that is fair, with others. Thus, Cicero's lovers of justice will be uplifted when they bring justice into the world, and they will yearn for it when they let it slip away. In this sense, the opportunity to encounter others in fairness is an opportunity to experience the fulfillment of selfhood in the ecstatic relationship where selfhood also dwells. And this is, correlatively, why it is said that "peace of soul... results from justice" (Sheen, 1954: p. 231)—when right-minded people acquit themselves through acts of justice, they feel the peace of an untroubled conscience.

Correlative to this notion that internal peace is created through acts of justice (pax opus justitiae) is the idea that, among upstanding people, a fundamental distress is found where justice is not present, distress not merely in the strained relations that occur between victim and perpetrator, but also in the inner life of those rightminded people who suffer or commit an injustice. ${ }^{17}$ Indeed, when the love between justice and man join them as

\footnotetext{
${ }^{15}$ Or (Aquinas, ST, I-II, Q. 91, a. 2). Again, from Vatican II: "Man has been made to perceive ever increasingly the unchanging truth in order that he may form right and true judgments of conscience.” (Bishop, 1966: p. 680 [abridged])

${ }^{16}$ Moreover, while it is true that the origins of justice could play a determining role in the advancement of moral theory, that sort of question is not the concern of an introductory approach to the relation between ethics and the self.

17“'A sin against one’s neighbor is an injustice that claims two victims, both the neighbor and the perpetrator.” (DeMarco, 1996: p. 133)
} 
one, “justice belongs to the actual existence of man as he is” (Hofman, 1956: p. 161), such that he will ever-experience joy in its manifestation and misery when it is forsaken. This is, of course, the theme of Dosteovsky’s great novel, Crime and Punishment, in which the author detailed the unbearable suffering of Raskolnikov who had done wrong with the naïve view that his unjust action would turn to his advantage. Indeed, it is clinical experience with the absurdity of this disordered hope, that leads Donald Carveth to advise us that, "Either we suffer consciously, bear our guilt, and strive to make reparation or if we refuse, suffer myriad forms of self-punishment... In my view, manifest appearances to the contrary, no one really gets away with anything” (p. 39).

Of course, we have already recognized that conscience is an inter-relational faculty. Note, however that even torture is inter-relational, that it requires a deep awareness of the other in order to gauge what would bring the most suffering and pain. With such possibilities in mind, it is clear that inter-relationality can only be noble when it is just. Thus, it is the task of authentic inner justice to monitor inter-relational experience with a view toward being responsible or fair. When one thinks have I been fair, regardless the words one uses or does not use in that often-wordless moment, moral justice (as opposed, for example, to legal justice) is taking measure of the situation and reporting its findings to conscience. Then conscience (as manager of the relationship between justice and the authentic self) delivers pride and peace, when the answer is positive-shame, guilt, and anxiety, when the answer is negative.

A technical problem with respect to understanding the relationship between conscience and justice is the question of whether or not they are the same thing. To be frank, it is impossible to mark precisely the boundaries of these two phenomena; but this is true of all mental phenomena as they can never be finally delineated in the manner of physical objects. This means that, while one can think of justice as an entity that is totally separate from conscience, that stands alongside it and reports to it; it is also possible to think of justice as something that resides within conscience. And, in order to understand a writer on these subjects it is important to know where that writer stands on this relationship. In the current case, for example, justice has been set apart as a quality that is distinct from conscience in order to delineate their separate roles: where justice evaluates fairness and conscience manages the relationship between justice's determination and the self. Without justice taking its measure, conscience would have nothing to report; and, without conscience forming its moral reaction, justice would be no more than an abstract measure (i.e., one would know one had been just or unjust, but would not care).

Common expressions such as "a troubled conscience" characterize the agitated state of a person who has not delivered justice to another. Expressions such as, "the dead call out for justice” are also suggestive in that regard, for such a call is performed not by the dead, but by conscience as it haunts our dreams. Of course, the classic representation of this sort of troubled call for justice by the conscience occurs to the narrating character in Edgar Allan Poe's “The Tell-Tale Heart”, whose own sense of having committed an injustice is so powerful that he hears his conscience accusing him in the loud beating of the murdered man's heart, coming from beneath the floorboards. ${ }^{18}$ Yet it is important to remember that, just as conscience can bring the acting person misery when justice and fairness have been denied to the other, so can it also bring that joy and peace described by Sheen and others, a joy that arises when a sense of fairness has led to proper action. The source for joy and peace of conscience, then, when one can affirmatively answer the question have I been fair, is the proper achievement of authentic inter-relationality (i.e., being proper to myself by being proper to my others), and it is derived from the following formula: as my truest self satisfies its inter-relational duty (i.e., justice/fairness), conscience allows me to feel the balance that exists between who I am as an acting person in the world, and that vision of self (eudaimon) that I carry with me as the north pole of my proper life. To use this statement as a source of contemplation is to make one present to the phenomenology of justice; and it is with a view to this phenomenology that Socrates spoke the well-known words, “pity the unjust man”. Pity him, for there walks a soul, self-abandoned.

On the one hand, we see the self-abandoned soul in the writing of Adolf Eichmann, who spoke of the holocaust with the clinical detachment of a technician and said regarding his role in it, "In actual fact I was merely a little cog in the machinery that carried out the directives and orders of the German Reich. I am neither a murderer nor a mass murderer" (Eichmann, 1961: p. 21). Here we have an example of what Turro refers to as the dead

\footnotetext{
${ }^{18}$ One might reasonably argue that the character hears the beating heart because he is insane. All the same, from a literary perspective, it is engineered by the writing author to associate guilt with the madness. Poe's madman might have heard chickens, horses, or seen meteors the author knew, however, that only the "sound" of the murdered man's beating heart would generate the narrative logic that led to the outcome, which is to say, he understood the role that "poetic justice’ plays in the reader's receptivity to an imaginative tale.
} 
(or, at the very least, seriously disordered) conscience, a man for whom pity does not come easily, ${ }^{19}$ a man whose sense of justice was so grossly distorted by culture that it neither sensed the man's nor his community's unjust and even abominable actions; and consequently had nothing to report to conscience at all. On the other hand, and in that same era, there is the story of Claude Eatherly, a pilot who participated in the Hiroshima mission and whose delayed guilt ${ }^{20}$ was so great that it led to years of socially dysfunctional behavior, extended periods in mental health wards, and countless pathetic attempts to self-punish and otherwise pay for his crime (e.g., letters of apology and explanation to the people of Japan, money sent to the people of Japan, various attempts to mobilize an antiwar movement, the Eatherly/Anders letters, attempted suicides). Eatherly was, indeed, pitiable and even pitied; and, at one point, a group of young women who called themselves the girls of Hiroshima wrote him. They began by saying, "We are all girls who escaped death fortunately but received injuries in our faces, limbs, and/or bodies from the atomic bomb that was dropped on Hiroshima city in the last war" (Anders \& Eatherly, 1989: p. 25). However, they concluded with the words, "We have learned to feel towards you a fellow-feeling, thinking that you are also a victim of war like us” (Anders \& Eatherly, 1989: p. 26). Eatherly's life unfolded, that is to say, as a form of misery that evoked pity even from his erstwhile enemy; and all as a result of an inability to make right an injustice. In both Eichman's and Eatherly's case we see what Kierkegaard referred to as the sickness of the self. Eatherly's sickness was that he had brought irreparable damage upon his authentic self (losing a self) by participating in a morally horrendous act and Eichman's was that he did not even know that he had an authentic self to damage.

Justice is, thus, a demand that one takes up under the supervision of conscience, as a result of one's inter-relational nature, in order to be one-among-the-others. We experience it in consequential states such as remorse, shame, and guilt. But we can also experience it proactively as a motivation, not only to repair the wrong that we have done, but as a motivation to do good.

Now clearly, the faculty of justice does not arise under all circumstances-people are often unfair to each other. They fail to live up to a just standard because of such factors as thoughtlessness, agitation, inexperience, and irresoluteness (Pieper, 1966: pp. 12-14), or they allow those who claim authority in the situation to regress them in the direction of small children, or efficient cogs in a social machine (Mittscherlich, 1963; Milgram, 2009). Such failures are not malicious, however-more than anything else, they suggest a forgetting to contemplate deeply the meaning of the situation. Indeed this is the value of the restorative justice process in schools today-it provides students the opportunity to contemplate the relationship between their impulsive actions and their own sense of fairness with respect to others. Restorative justice, in this sense, does not merely repay or punish for unfair action —at its core it provides an opportunity for a perpetrator's conscience to come alive in its assessment of the fairness of an act.

To some extent, justice is a social convention, simply because the sense of it is shaped by social context. Thus, even Aristotle, who wrote so systematically on justice, nevertheless was limited by his own culture's grasp of the just when making sense of it. His arguments with respect to women are notable examples of his socially inspired narrowness. Nietzsche understood this problem, of course, but saw no more than it; and, therefore wrote quite cynically that, "the source of conscience is faith in authorities" (Nietzsche, 1971: p. 323). On the other hand, as two great German humanists point out, there is:

a great psychological difference between the collective conscience... And the individual conscience (in which insight can overcome the rigid internal directives of censorship); the latter comprises the step from being a ward of society to full social membership (Mittscherlich \& Mittscherlich, 1975: p. 81).

Correlative to this distinction between what they call the "collective conscience" and the "individual conscience" (what we would call mature or authentic conscience) one can also distinguish between collective justice and authentic justice, the latter being distinct from the socially constructed variant. The justice of the court (i.e.,

\footnotetext{
${ }^{19}$ "Because his conscience was grotesquely distorted, it is right to think of Eichmann as a monster. Nevertheless it should be remembered that his character was in large part shaped by distinctive cultural, political, military, and bureaucratic milieu. That milieu may not be entirely unique. Consider for example, the planner and executor of mass-destruction in modern warfare. Behind a screen of technical language the fates of thousands and perhaps millions are coolly manipulated” (Selznick, 1992: p. 178). Thus, Joe Stiborik, the radar man on the Enola Gay said, "for me it was just a bigger bomb.” And, similarly, Harry Truman, who had ordered the bomb "announced in a public interview, that he felt not the least 'pangs of conscience'... (and)... named, as the only wrong worthy of his repentance, that he didn't marry before his thirties" (Anders \& Eatherly, 1989: p. 4). In this way, if no other, they are like Eichmann: "sweeping the deed from the desk of life, as if the too big guilt were not guilt at all. In order to master it, one makes no attempt to master it.” (ibid.)

${ }^{20}$ See the section on reflexivity.
} 
collective justice) is not always the justice of conscience.

And finally, justice is in some sense a burden, for it limits the ability of any individual to maximize personal power. Shakespeare, in what seems to be a channeling of an unborn Nietzsche, tell us precisely this: that the man whose conscience is triggered by justice becomes a coward, declines to take what is not his, is cautious in speech, and takes not the woman that he wants. The bard's words slander conscience as the very spirit of shame, a force that rebels against a man's yearnings and fills his path with obstacles, leaving all who hold to it beggars in the end. But of course, the character who speaks these lines is a murderer. ${ }^{21}$

With all this in mind, we can come to a deeper understanding of the notion of justice by referring back to Cicero's claim that all virtuous people love justice. Justice, using this as the definitive characterization, monitors the ecstatic relation that exists between the self and its relational world-one that fuses the "lover" and justice, itself. And this is also why Aristotle claims that "Justice is often thought to be the greatest of virtues, complete virtue in its fullest sense, because it is exercised not only for oneself, but toward one's neighbor also" (Aristotle, 1996: p. 5, 1, 27-33 [abridged]). When justice acknowledges fair treatment of the other, conscience adorns the self with states ranging from contentment, peace, and harmony to ebullience, righteousness, and divinity. When justice recognizes maltreatment of the other, conscience saddles the self with longing, anxiety, and sometimes madness.

Injustice brings the false into the world, a falseness that infuses everything it touches. Conscience, by managing the moral phenomenology of the acting person (we might also think of this as the spiritual life of the individual, or the state of the soul) takes up the call of justice and works to prevent those miseries (to others and to the acting self) that befall humanity, by proactively urging conscience in the direction of righteousness; or (where justice has already been overlooked) by retrospectively stinging conscience in the direction of moral repair. In order for this to take place, however, conscience must learn to distinguish its authentic presence from the conscience of the herd. This can only occur when reflexivity arises in the acting agent, which will be discussed next.

\section{Conscience and Reflexivity}

"Conscience is above all a reflexive concept.

It implies self-criticism and hence self-observation.”

(Loevinger, 397)

Buber calls reflexivity "self-illumination, the first and opening event in the action of the great conscience," (Buber, 1971: p. 34) and he takes up this position around a parable of a man who stands waiting at a door his entire life only to find at the moment it closes that it was his destiny never to enter but only to stand on the outside. For Buber, this is an allegory of the condition that brings about eternal standing in all of us-our failure to exercise reflexivity of conscience as the source of an individual's disposition toward the world. Practically speaking, this failure is associated with the missing of genuine opportunity in life, the common theme of Kafka's major works. Instead of being occupied with the authentic, in such cases, one becomes absorbed in comfortable and distracting conventions.

Comfort with conventions regarding what one must do begins at a very early age. A small child learns a tremendous amount about social behavior simply by imitating others, for example, and this can continue across a lifetime. Even adults may allow ridiculous customs they see around them to serve as a pattern for their own moral behavior - sidestepping any crises with respect to morally appropriate choice by doing what authoritative supervisors do or command, including, by times, what is contemptible because "the most potent quieters of conscience are evidently the presence of others who are doing the same things” (Glenn Gray, 1971: p. 272). However, the reflexive moment for an individual will occur when the everyday pattern of everyone else no longer satisfies that acting agent, who then asks instead, what is it that I must do in order to be myself? Reflexivity, then, is a state in which one self-distances from the deeply-internalized conventions and routinized customs that govern the matter at hand in order to see how personal conscience authentically regards the matter. So it is written

\footnotetext{
21“'I'll not meddle with it. It makes a man a coward: a man cannot steal but it accuseth him; a man cannot swear but it checks him; a man cannot lie with his neighbor's wife but it detects him. 'Tis a blushing, shamefaced spirit that mutinies in a man's bosom. It fills a man full of obstacles. It made me once restore a purse of gold that by chance I found. It beggars any man that keeps it. It is turned out of towns and cities for a dangerous thing, and every man that means to live well endeavors to trust to himself and live without it.” (Shakespeare, 1974: R3 A. 1, S. 4, lns. 134-145)
} 
that, "we respond to conscience only when we can separate ourselves from others and become conscious, often painfully so, of our differentness” (Glenn Gray, 1971: p. 272). This is apparently what happened to Claude Eatherly, the pilot. At some point after he played his role in the Hiroshima bombing, he awoke to the space between what his society said was right and what his authentic and awakened conscience told him was right. In many ways, of course, it was too late.

Illustrations can be much less disastrous and unusual, of course. Young Tom might listen while a group of boys say salacious things about a girl whom he regards as a friend-he might even laugh at some of the statements and never have another thought about it, simply because he has allowed the group disposition to shape the way he is experiencing the event. If, on the other hand, Mary should text him at that moment, or walk past the door, or if he thinks about a moment when Mary stood up on his behalf, he may set aside the group's attitude and ask himself how he truly feels about this malediction, possibly then leaving or telling the other boys that they are behaving inappropriately. Such are the ways that reflexivity may be triggered, causing a person behaving in a most everyday, albeit improper, manner to pause and wonder whether a social custom is one that his or her own moral conscience can truly embrace. Of course, there are countless other examples of occasions when reflexivity arises - various circumstances provide various conditions under which individuals will think differently than the people around them. Eatherly, again by way of example, may have seen photos of the Hiroshima victims or read articles in magazines sometime after the event; and this or something like it, in combination with his role as scout pilot, may be what triggered reflexivity in him. The critical requirement is that the moment occurs, the moment when a person questions an action whose only moral authority is that everyone else is doing it. Reflexivity as servant of conscience, then, can arise when a person psychically disengages from routinized cultural scripts in order to assess the relationship between those scripts and whatever sincere conscience the acting agent truly possesses. It can occur to a person participating in malicious gossip, a person participating in a group that mocks or shames some other person, or a soldier about to march on an enemy force. The folk expression covering its emergence is, "Just because everyone else is doing it, does this mean it is also right for me?"

The failure to be reflexive disturbs the relationship between the conscience and moral acts, but it can even subvert the discovery of conscience, for it is only in our capacity to self-distance from the conventions of the group that we have an opportunity to determine the relationship between these conventions and how we stand as distinct selves in the world. ${ }^{22}$ Further, it is through these acts of reflexivity that conscience places us in contact with the authentic self-indeed, it is through reflexivity that we know the right that exists for us, apart from custom.

Thus, reflexivity may awaken conscience. But conscience may also awaken reflexivity by generating (through its relationship to justice) guilt, shame, and anxiety within a person—an "inner malaise" (Henry, 1973: p. 117) that may nudge the acting agent in the direction of reflexive examination. The relationship between conscience and reflexivity is bi-directional then, a two-way street.

Another reversal is possible. For it is not only the case that ignoble others trigger reflexivity in a noble self an ignoble self may also be triggered to experience reflexivity through the noble actions of others. Thus, anyone acting thoughtlessly and narcissistically may be drawn back to an awareness of authentic self and true conscience through observation of noble community action, or through being observed, in the midst of his own ignobility, by others for "applying to myself the same standards I apply to others enables me to get free of myself and to examine myself from an intersubjective point of view" (Little, 1971: p. 23).

There are still other forces that mask conscience, including "superstitious fears, taboos, and a superego wholly unrelated to concern for moral rectitude" (Dolan, 1971: p. 23). The authority of each of these Pretenders standing in as conscience must be undercut by the reflexive act in order for genuine conscience to manifest.

Desperation also masks the possibility of authentic conscience. Aquinas, himself, knew that an injured body, a lack of food and basic needs, wars and civil unrest could block the very possibility of reflexivity (Aquinas, 1945: p. 60$)^{23}$. The common expression desperate times lead to desperate measures is quite appropriate here. But of course this does not mean that guilt and shame will fail to come and haunt, by way of conscience, when desperate times have passed.

Reflexivity is both a developmental and a situational quality. Over time, experience, and commitment, reflex-

\footnotetext{
${ }^{22}$ Ongoing failure to exercise this sort of reflexivity, it should be pointed out, is at the heart of Kierkegaard's third form of despair- not knowing you have a proper self.

${ }^{23}$ Or (Aquinas, SCG, III, 37).
} 
ivity approaches habit. For those to whom that happens, the actor becomes recognized as one with a well-articulated conscience. Nevertheless, even where a person has a mature conscience, the sweeping force of community and custom can draw the agent back into collective moral force-thoughtlessness, agitatedness, irresoluteness will recur-and the agent will require reflexivity to draw back again. The fully mature, constantly activated conscience is more rare, that is to say, than the occasionally mature one. All the same, once capable of reflexivity, the acting agent enjoys the possibility of living authentically, through making conscience-laden choices rather than conventionally laden ones. ${ }^{24}$ The value of reflexivity is powerfully expressed in the following quote. Though the particular circumstance that prompted it has passed, the general notion of the crisis is as real as ever, as is the reflexive solution he describes:

With weapons of world-destroying potential already at hand, it is imperative that we reaffirm the responsibility and protect the right of each individual to form a personal moral judgment concerning the military programs and policies of his nation's rulers. The day may yet come when the conscience of some disobedient soldier may be the last remaining hope for the survival of man (Zahn, 1971: p. 232).

\section{Conscience and Mindfulness}

Reflexivity creates the moment of moral awakening for conscience. But conscience can easily drift back into a sluggish sleep after that reflexive moment has passed. Mindfulness, by contrast, is the steady state of moral alertness; and the mindful person is one who keeps conscience steady and at hand in order to preserve self-dignity and an authentic relationship to circumstance. We can contrast the two ideas by saying that reflexivity is the alarm clock that awakens conscience while mindfulness is the caffeine that keeps it steadily alert; thus making clear that they are both instrumental in the application of prudence and justice under the various circumstances that they arise, including the way they manifest themselves in the moral virtues.

The state of mindfulness is, generally speaking then, a state of self-present-awareness; and, when a man (for example) is said to be mindful, it means he is attuned to his selfhood in the world-is aware that he exists as such and such a person who holds his self to such and such a standard in a community that is of such and such a form. As a functioning part of his humanity, then, his mindfulness is a constant negotiation between who he is and how he acts.

Failures of mindfulness occur when people fail to take regard of who they authentically are, in the midst of activities. The woman who says something she later regrets, the man who explodes in anger-these sorts of things are less likely to happen to the mindful person who is, by definition, alert to the situation and the implications any response to it will have on who he or she is. Conscience, thus, manifests in the presence of mindfulness when acting persons are constantly aware with respect to the relationship between who they are and what they are doing.

Failures of mindfulness give rise to moral mistakes, a category discussed by Aristotle in his characterization of justice. They are certainly not good things, but they are not malicious, for they are the product of oversight, not a will to harm. Gossip, bullying, insulting, cheating, and any number of other moral failures can occur under such unfortunate circumstances. Mary may laugh at Tom's telling of an ethnic joke because of a failure of mindfulness. She may forget that her husband's parents, indeed her own parents, came from the country that is disparaged in the joke, or she may not be immediately in touch with her own moral position on multiculturalism. In such a case, she may explain the behavior afterward by saying "I wasn't thinking"-a reply that is often accepted because listeners realize they often make the same mistake! By contrast, if Mary is mindful, her conscience will be alert, and she will immediately notice and possibly stand against the ethnic joke when she hears it because those who are mindful tend to remain aware of the interests and perspectives of others when circumstances of justice or injustice arise; tying, through their conscience, the dignity of their own selfhood to the way that they relate to others and their world for reasons explained earlier.

Both mindfulness and reflexivity are proactive in that they can occur before moral mistakes are made and thus contribute to making us better people, "for it is innate to the conscience of man that it can elevate itself" (Buber, 1971: p. 101). The two states allow the acting agent to survey, with conscience, imminent and future action, insuring that such action will show proper attention to (1) who the acting agent authentically is, and (2) what the

\footnotetext{
${ }^{24}$ This does not mean that the acting agent is authentic only when opposed to conventions. Convention may play an important role in the conscience of a person. However, convention does not play the determining role, for conscience is "ultimately an image of the ideal, a man who will acquit himself in whatever situation with independence and dignity” (Glenn Gray, 1971: p. 283).
} 
acting agent is doing. Thereby, reflexivity and mindfulness reduce the likelihood of self-betrayal while fostering the possibility of self-realization. But, even where self-betrayal has already occurred, these two qualities have the potential to arise after the fact, to lead (through reflexivity) to a suddenly awakened recognition that reparation is due and (through mindfulness) to an ongoing alertness regarding the burden one now carries. For these commitments to be realized, however, certain other qualities must be well developed, including will and courage, which will be discussed in the next two sections.

\section{Conscience and Will}

There are a variety of forces that motivate a person's action in a particular moment and not all these forces are expressions of a deliberative consciousness or conscience. Nevertheless, any one of these forces-pain, fear, anger, hunger, exhaustion, desire-any one of these or so many forces like them may stand in opposition to the completion of an intended act. Thus, a woman may overhear several people make disparaging and untrue remarks about a friend, and while her conscience may call her to object to this gossip, her fear of the speakers may prevent her from doing so. Similarly, a boy's conscience might tell him that he should keep his promise to help his brother with their post-party chores, but his laziness may entice him to break that promise. Clearly there is a chasm that separates a demand of conscience from an achievement of conscience and something must act as a force that allows the person to spring from the former to the latter, across time. One of these forces is the will.

The human will is one of the unique achievements of humanity. On the one hand, it carries an intellectual dimension that is attached to consciousness itself. This is the aspect of will associated with knowing in the present moment what one intends to make good at a future moment. But such a knowing would not be a sufficient condition for the will as we experience it. Rather, will possesses, along with its self-aware intention with respect to the future, energy resources necessary to make that future come to life, what is commonly called willpower. Now, this willpower can be put to several purposes. On the one hand, it may be transformed directly into the physical labor necessary to accomplish a task, as occurs, for example, when a fireman carries a child out of a burning building. On the other hand, it can be used to resist other forces that arise within the self, psychic and physical forces that misdirect or restrain the intention championed by conscience. The fireman may, for example, be afraid of the fire he enters, or he may be suffering from the effects of the heat, possibly even the flame. Should these sensations and emotions work against his original intention to rescue the child, the energy of his willpower may aid him to set them aside. Thus, where will is attached to conscience, it functions to set aside other determinations that might arise (e.g., "run", or "let Tom do it"), holding the acting agent to task until the action demanded by conscience is completed. And so we see how important will is to a peaceful conscience, for will is the quality of a person that gives duration to intention. ${ }^{25}$ Nietzsche characterizes this when he suggests that the will continues in time even after an intention has been initially formalized as:

... an active not wishing to be done with it, a continuing to will what has once been willed, a veritable "memory of the will"; so that, between the original determination and the actual performance of the thing willed, a whole world of new things, conditions, even volitional acts, can be interposed without snapping the long chain of the will in order for him to stand pledge for his own future as a guarantor does (Nietzsche, 1971, p. 28 [abridged]).

However, it should be recognized, that the will is, in itself, no guarantor of noble action for one can will evil as forcefully as one wills the good. It is only when conscience (as inter-relational caretaking and justice) becomes a concern for the will, that will achieves its proper and complete relation with selfhood. Thus, the personal will to power (the narcissistic will) must face "another and higher task, that of disciplining itself and choosing such aims as are constant with the welfare of others and the common good of humanity (Assagioli, 1973: p. 86).

The character of conscience and will is closely connected with the "will to community," characterized by Rudolph Allers as "a primal tendency of human nature" (Allers, 1931: p. 77). Allers sees intimations of this quality in animals and insects but regards the human variant as something beyond the community expression of other living things, regards it as both a fundamental feature and peculiarity of human nature (p. 77). He associates the idea with Aristotle's classic conception of humans as zoon politikon and goes on to remind us that medievalists understood the philosopher to mean sociable in the context of the term's usage. ${ }^{26}$ Thus, while he

\footnotetext{
${ }^{25}$ It is with this in mind that Buber characterizes one of the redeeming possibilities of humankind as perseverance.

${ }^{26}$-there being no word for social in ancient Greek. On the meanings of zoon politikon (see Depew, 1995).
} 
admits that there is an impulse toward self-preservation in the individual, what he refers to as a will to power, he also recognizes that "the moral goal of the will to community is love, love of one's neighbour and every other kind of love” (Allers, 1931: p. 78).

We can ground this notion of love in the concept of bond need, characterized in the writings of sociologist Thomas Scheff (1994). And the fact that a bond with others is a condition for things such as upbringing, protection, and nurturance stresses the role that love plays in survival. At this level humans can be understood, like other species, as creatures that possess co-relational impulses. However, by virtue of the fact that they are also temporal creatures (i.e., able to plan) they are also able to maximize the effectiveness of their mutual concern, through willing their co-intimacies - their promises, agreements, negotiations, and so forth. It is in the context of community relations - a context within which people know and rely upon each other - that this "will to community" flourishes, granting one the ability to will a provisional loss in order to negotiate a balance in the relationship. Thus, for example, if a young man wants to go to a football game and his partner wants to go to the ballet, the will to community may cause the young man to forgo narrowly-conceived, self-gratification for the sake of the relationship, and attend the dance performance instead. Here we can see the relationship between the will to community and Erik Erikson's notion of mutuality as the foundation of all healthy relationship.

The will to community is bolstered in genuine community life; for example, in a context where the man who shingles Mrs. Smith's roof has two children who will have Mrs. Smith as their teacher for the third grade. For such a man, if he finds damage beneath the woman's old shingles, he is more likely to repair it because he recognizes that both he and the teacher are co-invested in a single community system. However, in social orders where production is dissociated from relationship (i.e., where the roofer is looked up in the phone book), the will to community is easily subverted (i.e., he is more likely to simply nail shingles over the hole, knowing he will be long gone when it turns into real trouble) because the relationship and its accountability is not extended across time, a notion well expressed in the words "take the money and run". Indeed, in any context where social life is fragmented, alienation of the one person from the other is the norm, so that we find ourselves in the unenviable period that Martin Buber refers to as the "epoch of homelessness". ${ }^{27}$ The best way to conceive of Allers' will to community is, then, through the classical commitment to ethos as the quality of action that surrounds one with a dwelling place (Kenny, 2004: p. 34), achieved through a will that is vitally mobilized by conscience. Students should understand, then, that they will not have the protection of their family, friends, and coworkers if they do not fill that community with others committed to the relationship between conscience and the will—also that they will not deserve that protection unless they also foster a will to community in themselves.

At the heart of conscience and will is the notion that conscience would remain unanswered without an agent's capacity to make and fix a determination. On the other hand, any moral determination would be arbitrary or corrupted if it were not linked to authentic self-being through care for others. Thus conscience and will combine as a singularity to bring out the best in human beings. Where one is weak, the other falters. Therefore, it is important to develop those qualities that fortify the will, one of which is courage, discussed below.

\section{Conscience and Courage}

Courage is closely associated with the will as a mechanism for achieving the goals of conscience. This is because the proactive conscience, the conscience that encourages acts of goodness and authentic selfhood, must do so facing risk and loss; and therefore a person who wants to do the right thing often feels anxiety and fear. Of course, many will back down when that happens, but not the courageous person, who refuses "to be forced into evil by fear, or to be kept by fear from the realization of good" (Pieper, 1966: p. 126). Thus, courage is not the exclusive property of the superman who cannot fail, nor is it to be conflated with a narcissistic will to power (i.e., a will to overcoming). Courage also belongs to those who have a will to community and a will to endure; and this means that the weakest among us can stand with courage in the most adverse of situations when conscience reminds us that we cannot, no matter how expedient it may be to do so, "blind ourselves to the other's suffering...cut off our empathy with the person needing help” (May, 1975: p. 17). Genuine courage can, indeed, show

\footnotetext{
${ }^{27} \mathrm{By}$ way of illustration, shortly after purchasing a new condominium, my mother, like every other owner, was required to place another $\$ 40,000$ in the condominium fund to have the exterior siding of the building renewed. It was impossible to seek compensation from the individual who had contracted the condominiums, for he had already dissolved the corporation he created explicitly to build it; and a number of residents were required to sell at a loss, as they could not obtain sufficient credit to pay for this additional expense. The repairs have been completed at the expense of the residents and, at this time, the contractor has formed a new corporation and obtained the right to build in a location that will block the original condominium owners' view.
} 
itself when there is no pleasant solution to the problem at hand, as is illustrated in the following story:

In the Netherlands, the Dutch tell of a German soldier who was a member of an execution squad ordered to shoot innocent hostages. Suddenly he stepped out of rank and refused to participate in the execution. On the spot he was charged with treason by the officer in charge and was placed with the hostages, where he was promptly executed by his comrades. In such an act the soldier had abandoned once and for all the security of the group and exposed himself to the ultimate demands of freedom. He responded in the crucial moment to the voice of conscience and was no longer driven by external commands (Glenn Gray, 1971: p. 282).

Here, in this narrative, we find the root of courage in its relation to conscience. For the soldier, there was no superhuman pathway upon which he could rescue those innocent people and rescue himself. His choice was only between (1) suffering, for the rest of his life, "the despair of the moral person" (Arendt, 1971: p. 245) who had become, like Eatherly, complicit with the unforgivable, and (2) being shot to death. He preferred, as Socrates said he would prefer, to die, rather than to live for ongoing decades as the one who had brought the death of innocents into a world. ${ }^{28}$ Thus, of courage, it has been written that, "one must be willing to bear the burden of unceasingly standing face-to-face not only with the dreadful reality of death but also with the mystery of nothingness" (Hyde, 2001: p. 71). Of course, to many of us, such "fortitude seems plainly unwise or stupid" (Pieper, 1966: p. 123). Nevertheless, it calls our admiration because it reveals to us the ultimate, self-actualization potential available to anyone fully willing, beyond the clutches of fear, to seek his or her proper self (i.e., eudaimon) - it shows us the very circumstance under which "the inmost and deepest strength of man reveals itself" (Pieper, 1966: p. 130). That is why we say it is courageous, then: because, "the courage to die is the test of the courage to be" (Tillich, 1987: p. 178).

The soldier's brief story shows both how remarkable and terrifying courage is-a terrifying power in the service of conscience, a determination to persevere in power "within our own being, without which we would feel ourselves to be a vacuum” (May, 1975: p. 13). For courage can only be fully realized when we recognize that there are fates worse than death, that the death of the body is a lesser loss than the death of the authentic self-a realization that this soldier's conscience forced him to recognize and acknowledge. Such a sacrifice can only make sense when we understand that "the brave man suffers injury not for its own sake, but rather as a means to preserve or to acquire a deeper, more essential intactness" (Pieper, 1966: p. 119). And in this truly terrifying, possibly fatal way, courage stands as servant to conscience. Seldom is it revealed as a physical power to transform or preserve the world (i.e., acts of courage do not typically resolve in magnificent accomplishments with no cost to self, the way that they do in Bruce Willis movies). More often, is courage a simple fixed resolve to steer one's ship, under threat of anxiety, suffering, or loss (on many occasions without measure), in the direction encouraged by conscience. The courageous person, then, responds to the demands set forth by conscience and proceeds, regardless of the consequences, in a manner that is coincident with the light of truth. And this is why it has been written that, "whoever realizes the good by facing what is dreadful...is truly brave" (Pieper, 1966: p. 127).

Fear creates helplessness by paralyzing the will—surely we all have been in that situation. And, indeed, the soldier who gave his life, rather than take life, might have failed to stand with his conscience on a dozen other days. Whatever was the case, once he found his courage all the other qualities of conscience were manifested in him - this is the essence of fortitude; and it is the reason Winston Churchill "ranked courage as 'the first of human qualities because it is the quality which guarantees all the others"” (DeMarco, 1996: p. 47).

But, of course, the risk of injury or loss is precisely the reason that most of us stand down in the face of radical challenge; for popular wisdom tells us that only an idiot stands up against impossible odds. We are thus much more calculating with respect to our acts of so-called bravery. And in this thinking, we are very close to Aquinas's explanation for why courage fails: for he says that failure of courage is a result of disordered value. Aquinas would suggest that our prudent sense of when to stand down is actually a false prudence because it sacrifices a greater thing (human integrity) for a lesser thing (e.g., a good, a service, an opportunity). Correlative to this criticism, Aquinas believes that a person who gives priority to the right things will understand where and when courage is necessary.

Granted, many will argue that it is better to live as a sinner than to die as a saint; and it is certainly hard to sell a classroom of college students on the idea of dying for the good. Nevertheless, we seldom are challenged to sa-

\footnotetext{
28“'Socrates is certain that the self which the executioners will destroy is not the self which affirms itself in his courage to be.” (Tillich, 1987: p. 177)
} 
crifice our lives, or even great worth, for the good. Many of the risks associated with courageous conscience are small. Therefore, a question that can be derived from the issue of disordered value should be put to students: what are the things so important that you would covet them, even if it meant betraying the people that you love or love you? A young man who is not reflexive, for example, may quickly lie to a romantic partner or parent in order to avoid disagreement or consequences. To that young man, it may appear as if lying under such circumstance is an "easy fix" or a "no brainer". However, if reflexivity is triggered he might ask himself, "What is the price I and the people I love will pay for this lie?” Then, recognizing that the price is the diminishment or obscuration of his authentic self and the theft of the other's free choice, he may decide, "No, it isn't worth sacrificing this much of the truth of myself and creating a barrier between my essential self and my most intimate others by telling this untruth." Should this occur, the young man would be establishing value in authentic selfbeing and inter-relational integrity, and measuring this value against the value of being able to sneak off without detection or maintaining driving privileges with the family car. For this young man, when the time arose to tell the truth, there would surely be fear-there is always fear. And possibly there would be loss as well. He might, nevertheless, courageously choose in keeping with conscience, facing the risk of loss-not because of fearlessness, but because of a more specific grasp of what he was authentically unwilling to risk: his ability to stand on behalf of his others and thereby in the same moment stand with his authentic self. And, should we hear him make such a response to the call of conscience, might we not also resonate with "the authenticity that caused him to sound the call” (Kenny, 2002: p. 251). One does not need to be on a battlefield in order to blossom the flower of the self. Nor are these rare occasions-they happen every day. ${ }^{29}$

We must never allow such an argument to blind us, however, to the terror that arises under many circumstances when courage is called for by conscience. Many a good person, that is to say, has violated the demands of conscience because of fear. Being brave is not easy, particularly because the idea that one might willingly suffer has become "antagonistic to contemporary culture" (Henry, 1973: p. 112). Nevertheless, "a decent society requires the embracing of deprivation and pain as a normal and regular component in living together," because, "without depriving oneself, protection of others can rarely occur" (Henry, 1973: p. 112). We need, that is to say, the authentic courage of others; therefore we are obliged to give our authentic courage to them.

\section{Situated and Habituated Conscience}

Most of the writings in contemporary discourse about conscience treat it in terms of its presence with respect to a specific situation, within which an event is about to occur or has occurred-conscience, triggered at that moment, renders its judgment of what is about to be done or what has been done. While this sort of situated conscience is very important to self and self-development, it does not yet characterize a fully-mature conscience because the moral judgment of a conscience is significantly determined by the habits of the actor who engages it. Conscience, it should be understood, is ongoing, and not an occasional matter, so that a truly discerning conscience arises and is preserved in a person who is in the habit of acting with propriety. And, associatively, a poorly used conscience will eventually become, because of this habitual misapplication, an erroneous conscience (a conscience that errs). The idea is important enough for an author in these studies to form of it an aphorism: "If we fail to act as we really judge, we come in time to judge as we act" (Dolan, 1971: p. 18). Thus, a man who has lived in a world where striking others is a customary solution to feeling anger is far more likely to strike others when angry and far more likely to feel pangs of conscience for not doing so, rather than to feel the moral pain that most readers would feel if they did. Given such ideally corrupt conditions, that is to say, "murder is as impersonal as the squashing of a gnat" (Arendt, 1978: p. 22); and a person accustomed to such practices would be one who "has come to terms with a corrupt style of life and is so thoroughly installed in his habit that he experiences no qualms or remorse... and can now act unchastely and 'in good conscience”” (Dolan, 1971: p. 17).

A conscience that is distorted by bad habit explains the comfort some people have had historically with atroc-

\footnotetext{
${ }^{29} \mathrm{~A}$ college student told me in class that she had been in a traffic accident the night before. The investigating officer told her that, had she exited the intersection before the light turned red, she would be deemed the party not-responsible, and her car would be fixed by the other person's insurance. The officer then told her that she was the only person who might be able to confirm whether the light had changed or not Her faced glowed with pride, as she described how she admitted to the officer that the light had turned red, meaning she would be the responsible party. She added that, so proud of what she had done, she later shared the whole story with her parents, who said to her, "Couldn’t you have waited till you own your own car before you start this commitment to radical justice?” (:) Later they admitted that they too were very proud of her.
} 
ities, but it also explains some of the situated blindness that occurs within our own society as well—blindness with respect to the treatment of animals, the spoiling of the environment, wars being waged in our names, the substitution of a morality of consumption for a morality of authentic self-preservation, and the lack of discretion with respect to sexuality and intimacy. This is the condition characterized by Arendt when she says, "the psyche can be destroyed even without the destruction of the physical man” (Arendt, 1971: p. 222). Qualis unusquisque est talis finis videtur ei-whether the good is seen depends on the character of the person who is observing it, and the conscience of that person is qualitatively dependent on the manner that his or her character is cultivated, by society and by the self.

It is difficult to exaggerate the significance of the habituated conscience. One's habitat is the product of one's habitual conscience, in that one makes one's ethos, one's dwelling, from small moral decisions that accumulate on a daily basis, to form a life. The man who makes no habit of his conscience, who occasionally lies to his wife, shouts at his children, drinks to a point of stunning intoxication, shows up late for work, and cheats his fellows, gradually recognizes that these choices have affected the quality of everything that is around him (the anxiety in his children, his wife's attitude toward him, the state of his liver, the reliability of his friendships). Moreover, it is unlikely that a single or occasional act of conscience will redeem his circumstances. However, the opposite is also true: the man who makes a habit of proper conscience respects his wife, is temperate with his children, manages his drinking, is steady at work and honest with friends. On many occasions he too will see the product of his moral labor, a product, in all likelihood, much more positive than his counterpart's. Moreover, while doing so, he will cultivate his moral sensibilities in a manner analogous to the way that weight lifting fortifies muscles. Then, should a great moral challenge arise, he will be better equipped to face it by virtue of discipline.

\section{Conscience and Authentic Guilt}

Authentic guilt is a mixture of two things: feelings and thoughts—it is always both—it cannot be one. Thus, a guilty person both (1) feels discomfort and (2) thinks he or she has brought injustice or harm upon some other person or thing. Self-recognition as the bringer of injustice or harm, when it is associated with uncomfortable feelings, is authentic guilt. In this regard, note that the affective part of guilt, whether it be referred to as depression, anxiety, sadness, pity, self-disgust, despair, worry, yearning, or any combination of such emotions is not by itself guilt, and there is no explicitly guilty feeling, only some composite of feelings associated with the experience of guilt. In its essence, guilt is tied directly to justice: it is a cognitive-emotive composite formed from the affective burden associated with the recognition that one has not been fair.

The expression, "I feel guilty," though common, is largely misleading for there is no feeling that can be rigorously described as guilt. Rather, guilt-related feelings are a blend of emotions that has no universal character beyond its essential orientation in the direction of misery. Moreover the nature of guilt-related feelings varies with the amount of harm done by the action-for example, both a man who cheats on his spouse and a driver who kills a family in a drunken accident might experience guilt, but not in the same way (sometimes disgust with the self can be associated with guilt while at other times horror is the dominant sentiment). Moreover, selfdisgust may be so small that it leads to a shaking of the head or a few lines of self-contempt written in a diary, where on other occasions it can be of enormous, even suicidal proportions-illustrations of variation in the degree of feeling associated with a sense of guilt. ${ }^{30}$ Guilt-related feelings, in this sense, are best described as variations in degree of misery because that description does not commit the error of misplaced specificity with regard to the emotional nature or intensity of feelings present in a guilt experience. One can speak of guilt feelings and feeling guilty, of course, and people always will. However, it is important to understand that this folkish manner of speaking does not identify the true character of the guilt experience.

Now if guilt is not identifiable by the unique emotion that attends it, it must be recognizable from its cognitive aspect. This is true, and the role of conscience in the experience of guilt comes from this fact, for it is conscience that directs justice to monitor the situation while it also registers the degree of injury or harm to the inter-relational realm. Then, armed with the determination of justice, conscience delivers this information to the self, wordlessly saying, you are the bringer of this degree of injustice and harm. Of course the acting person factually knows already what he or she has done, even without conscience, but it is conscience that alerts the self to the moral character of the situation and bends the acting person to recognize this action as an inexcusable injustice imposed upon some other. Conscience says both: (1) there is an injustice and (2) you are the

\footnotetext{
${ }^{30}$ For example, where the object injured varies in value to the guilty person, the intensity of the guilt composite will vary.
} 
cause-it calls out one's guilt; and this is why "all awareness of guilt presupposes the capacity to respond as an individual to the call of conscience. I am using the term 'respond' in its original meaning of answer to a question or demand made on the self” (Glenn Gray, 1971: p. 272).

Neither the poorly developed person (e.g., the narcissist) nor the well-corrupted person (e.g., the sociopath) experience some composite of those miserable feelings that are typically associated with committing injustice and injury. For a narcissist, this is due to an inability to see things from another person's point of view or an unwillingness to accept information harmful to a narrowly-conceived (i.e., inauthentic) self-image. Such a one drowns out the voice of conscience, through strategies such as denial, splitting, detachment, blaming others, rage, and narcotics. ${ }^{31}$ And, to be sure, a lifetime of such strategies will leave the narcissist numb to the acute sting of transgression and absent all awareness of his own authentic conscience (and its proper demands). In such a case, "the erroneous conscience even when at peace can be an objectively guilty one... (that has simply) come to terms with a corrupt style of life and is so thoroughly installed in his habit that he experiences no qualms or remorse... and can now act unchastely and 'in good conscience'”(Dolan, p. 17). All this is preparation for the development of the well-corrupted person (see Turro's notion of the dead conscience, mentioned in this essay), who has the ability to comfortably deny, disregard, or distort the reports of conscience. For such a person, the tension between affirming and denying the demands of conscience resolves such that, "the negative side becomes an absolute value" (Pieper, 1966: p. 94); so that, in the end, it becomes possible to gain pleasure from the inversion of conscience itself- - what the scholastics called malitia, the signal and ultimate characteristic of the person who has turned in favor of nothingness (Pieper, 1966: p. 121).

On the other hand, the authentic, conscience-activated person has no effective strategies for escaping personal responsibility where it is justified. He or she will respond fully to the voice of conscience and therefore (1) grieve the injustice or injury suffered by some other or the world, (2) grieve for being the source of that injustice or injury, and (3) yearn to restore balance in the relationship. ${ }^{32}$ Often this creates the motivation for restoring the relationship between the self and the other, restoring it as one that is deeply underwritten by a need for balance (i.e., justice).

The idea of restoring balance is deeply inscribed in Western intellectual thought. Aristotle, for example, initiates a thesis on the restoration of just balance by citing the Rhadamanthine rule that "To suffer that which thou hast done is just” (Aristotle, 1996: NE, 5. 5). But he does not conclude that justice can be found in this principle, and he goes on instead to propose a sort of balance that has its own problems. It can be no other way, because reparation through equitable payment, exchange, or punishment is not always possible (e.g., if I kill another person by driving irresponsibly, there is nothing I can do to restore what the family has lost or what the dead person has lost). In such cases, the guilty individual is cast into an existential limbo (i.e., despair) from which self-injurious, persecutory guilt is likely to arise (Carveth, 2013). Indeed, it is in virtue of such fated, unredeemable circumstances that Heidegger characterized resoluteness (to be discussed later) as a condition of authenticity - a being-capable of enduring the necessary, along with a recognition that this "enduring” is now the proper manner of being, given what has come to pass. ${ }^{33}$

With all this in mind, it is critically important to distinguish authentic or ethical guilt from misplaced, distorted, or inauthentic guilt, because there are so many circumstances in which one can experience an unhealthy, unnecessary, deeply pathological, and unwarranted sense of responsibility. Social creatures that we are, it is possible for people to confound cultural condemnations that range from the careless (e.g., you forgot to phone your mother) to the vicious (e.g., homosexuality is a sin) with the natural care that is the consequence of interworldliness and inter-humanness. Because this is so, a woman may feel guilty for leaving a violently abusive husband, and a parent may feel guilty for letting a child experience the developmentally critical consequences of his or her own actions. People can also bear an excessive sense of guilt (and, correlatively, shame) after surviving desperate circumstances-Hiroshima survivors, for example, castigated themselves for failing to provide adequate care for others who were dying, for failing to convey people to safer ground, and for failing to visit and nurture the sick and dying (Lifton, 1967: pp. 31-56). This burden of guilt is disproportionate or misplaced, in that it does not take into account the guilty person's own psychic injury (and therefore crippling) in the midst of

\footnotetext{
31“The voice of conscience can be stilled in four ways: by killing it, by denying it, by drowning it, and by fleeing from it.” (Sheen, 1954: p. 91)

${ }^{32}$ Note, however, that this yearning to restore balance may not express itself in action that restores balance, for reasons set out later in this section. The result, of course, is a compounding of misery.

${ }^{33}$ For an extended treatment of resoluteness in this sense (see May, 1999).
} 
the most horrendous orchestration of human death imaginable.

And guilt can also be morbid, as it is for those whose lives have been so corrupted by circumstance that the opposite of goodness becomes the rule. Consider, for example, children trained to be soldiers in ancient Sparta, as well as contemporary Rwanda, Somalia, and Sierra Leone, to name a few. Having been so thoroughly inverted in their years of critical development, it is possible for them to feel guilt when they do not commit horrendous actions demanded by their leaders. But, of course, we do not need to travel to the other side of the world to see distorted or unmerited guilt in action, for our own culture is deeply invested in this guilt-gang behavior is a patent example, but we should not forget that our media and our daily conventions rigorously impose a discourse of the right and the wrong upon the general public too, a way of seeing that mirrors the culture's ambitions, generating guilt with regard to such things as body weight, sport failure and sport success, direct demonstration (even if accidental) of intelligence, and dreams or realization of high achievement.

Wherever cultures create an atmosphere of distorted guilt, the person experiencing it enters a state of moral turbulence, uncertain how to separate the genuinely right from the genuinely wrong in the context of those competing claims. But if conscience, as stated earlier, is the product of self and self-determination, then the morally confounded person must (1) strive for clarity of the self (reflexivity and mindfulness) and (2) allow that clarity to stand against the imposition of cultural insistence (through courage, will, and habit). In such cases, moral philosophers argue that the voice of clear, unmangled conscience should always rule over the voices of culture and authority (Cunningham, 1971; McCool, 1971; Morsell, 1971; Ratterman, 1971; Zahn, 1971).

In any event, such cases of persecutory guilt, ranging from unmerited, to morbid, to absurd are precisely the sort used to justify the popular contemporary notion that all guilt causes "inner malaise and is therefore going out of style, becoming obsolete, so that now the function of all ethical systems is to take the guilt out of life.” (Henry, 1973: p. 117 [abridged]) Yet coming to this conclusion requires overlooking the important role that authentic ethical guilt plays in keeping us true to ourselves. Indeed, "we cannot remove guilt from an ethical system without endangering decent human society, for the abolition of guilt removes the mechanism of self-criticism and the inner need to make restitution for a wrong” (Henry, 1973: p. 117). Moreover, it has long been recognized that the great psychic pain of guilt can sometimes lead to greatness in the development of character. On this topic, Martin Buber says, "I have met many men in the course of my life who have told me how, acting from the high conscience as men who had become guilty, experienced themselves as seized by a higher power. These men grew into an existential state to which the name of rebirth is due" (Buber, 1971: p. 116). Authentic guilt is one of the proper burdens inescapably entwined with human freedom—what Heidegger calls "wanting to have a conscience" (Heidegger, 1962: p. 288); and it is proper to embrace it whenever it is ethical and authentic, because the person who has caused injustice and unfairness but carries guilt for it is one degree closer to the necessary, life-affirming dignity of self than the person with the talent to deny or ignore that fact, or even gain pleasure from it. Nowhere is this expressed better than it has been by Donald Carveth:

We should feel such guilt; we should bear it; we should experience contrition; we should apologize; we should make reparation; we should seek to change in positive ways (repent) and seek therapeutic help if necessary to do so; and we should seek and accept forgiveness, provided our contrition and repentance are genuine (Carveth, 2013).

To this enlightened comment, one might only add that, where it is not possible to repair injury, or not possible to do so fully, the self can instead be healed through the long process that Heidegger refers to as resoluteness, the acceptance of both what has been done and what has happened, and the necessary burden that one carries in honor of one's now injured authentic self, a self that, awakened, would never have made it so. Other paths damage some other part of psychic integrity in order to persevere in a false and troubled innocence (Carveth, 2013). Thus ethical guilt and the honorable burden of resoluteness, that is to say, may be the only path to authentic healing possible.

\section{Conscience and Authentic Shame}

Authentic shame also responds to the occasion when conscience evaluates and reports a particular action and bends one to recognize it as unfair treatment brought by the self upon some other. But it is not, like the sting of guilt, focused upon being the one who has caused the injustice and the injury. Rather, authentically shamed people focus 
upon how their unjust actions give them a sense of diminished self-esteem, often called being or feeling ashamed.

The point of divergence between authentic shame and authentic guilt occurs when conscience announces one is the bringer of injustice. At that moment, compelled by conscience to look at the injury and the injustice, guilt drives the perpetrator to recognize responsibility (i.e., you have brought unjust harm) and its attendant sentiments. At the same time, still under the compulsion of conscience to face the injustice one has done and its consequences, authentic shame drives the perpetrator to experience a sense of diminished worth (i.e., you are less, for you have brought unjust harm). Authentic shame is thus also tied to justice because one can only recognize one's diminishment after allowing that one has acted unfairly (i.e., unjustly). It is the recognition that one has committed an injustice that makes one authentically shame-worthy - that is to say: the commendable ability to hold oneself to fairness and justice makes shame possible in the form of authentically being ashamed. Thus, authentic shame arises when one (1) knows one has been unjust, (2) knows one's self-esteem has been diminished because of this, and (3) suffers as a result of that knowledge. And, because the self does not want to be less than it is or to lose itself, authentic shame also plays a role in the yearning for reparation.

Of course, shame and guilt have a very close relationship; but it is important to maintain a clear understanding of how they are distinct, so that individuals troubled by matters of conscience can determine whether the crisis they face is primarily a guilt driven one or a shame driven one. The distinction between the two is often muddled because of the shame-guilt spiral, which begins when a shamed person experiences guilt for maintaining a status that he or she no longer deserves.

In order to illustrate this, let us take the case of Mary, who has acknowledged the accusation of conscience that she has engaged in an unjust action (which was, let us say, lying to her romantic partner, or to her boss, or to her best friend). Initially, Mary experiences guilt for what she has done, and shame may also arise as she realizes (in her experience of self-diminishment) that she is not the deserving lover, or employee, or friend that she had thought herself to be. Now, this is the first level of the shame-guilt spiral, and it would end here if she simply confessed the lie and made reparation. The second level begins, however, when, having recognized herself to be an unfaithful compatriot, unworthy of the genuine, truthful interaction the other gives her (because she herself does not give that in return), she nevertheless continues to benefit from the other person's treatment of her as the person she no longer is. Conscience will then report to her this new layer of injustice, a layer that gives rise to an entirely new level of guilt and shame-guilt for accepting a care that she no longer deserves and shame (a further diminishment of self-worth) for doing so. And, of course, even at this moment, if she does nothing about it in terms of reparation, another shame-guilt spiral will arise, driving her further and further in the direction of self-considered worthlessness - unless, of course, she ignores the entire matter, in which case, like Eichmann, she is completely lost.

Now people who are caught in the shame-guilt spiral will often characterize their guilt as a sense of worthlessness because the two states are so closely intertwined that one can hardly tell the former from the latter when it comes to the emotional experience. However, for the sake of resolving the matter, it is important to recognize that the sense of having done wrong (guilt) and the sense of being worth less (shame) are not identical even if they are conjoined - in particular because the latter can only be resolved through reparation of the former, which is to say one can only eliminate one's authentic shame by making reparation for one's guilt. Having said that, it should also be clear that guilt-sensitive people are likely to make reparation, but shame-sensitive people are less likely to do so. The reason is simple: guilt is concerned for the sake of the other while shame is concerned for the sake of the self. All the same, any attempt to manage authentic shame by hiding from it is misguided, if the goal is to come to terms with the self. True, many public figures disregard the call of conscience, protecting their public status and avoiding public shame through secretive and deceptive strategies. Nevertheless, one cannot continue to be an authentic self and hide from conscience-laden shame. That choice is injurious to the authentic self and can lead to such well-known disturbances as denial, projection, and splitting.

As was the case for guilt, the feeling-quality (the misery) for authentic shame varies from case to case and comes in varying degrees. Authentically shamed after telling a lie, one may feel modest anxiety and depression. Authentically shamed by abandoning a spouse or one's family one may feel great anxiety and self-loathing. The quality of authentic shame also varies with respect to the quality of relationship that exists between the self and the injured other-shame for betraying a faithful friend may be greater than shame for betraying one who has been, himself, unreliable, for example. In any case, the cognitive aspect of shame is the recognition that one is now lesser.

Of course, shame is not only brought forth in reflective acts of conscience, for other people may equally and 
easily shame one. Moreover, those others will not merely say, "you are less," they may also treat the shamed other as less, which could translate into loss of job, loss of family, loss of reputation, and so forth. Authentic shame (i.e., being ashamed) is private and makes one feel undeserving, anxious, and despairing with respect to both one's selfesteem and the warrantability of one's status. Public shame and interpersonal shame, whether they are coincident with authentic shame or not, come from others and represent a direct and immediate threat to both interpersonal and public esteem and status.

Based on what has been said above, it is clear that shame does not prevent confession and reparation-rather, confession and reparation are inhibited by the betrayer's anxiety with respect to creating interpersonal or public shame-loss events by telling the truth. This is because public shaming is the very social process by which esteem and status are removed in what sociologists call "degradation rituals" (Garfinkel, 1956)—the most obvious illustration being the military court martial. Indeed, this is why secretly ashamed individuals may avoid reparation (e.g., confessing, apologizing, and making amends), despite the burden of guilt and authentic shame. For them, fear and anxiety with respect to the possibility of public shaming, and in particular shame-loss (i.e., diminishment of social status and esteem) imposed upon them by the injured party and others. Found out, a betrayer may say, "I did not tell you because I was too ashamed," but this is technically not the case in that any authentic guilt or authentic shame felt would actually move the betrayer in the direction of confession and reparation, for that is the only way that authentic guilt and shame can be resolved. Moreover so long as the injustice remains a secret known only to the person who committed it, interpersonal and public shame could not be felt either - they could only be anticipated (i.e., the wrongdoer could experience anxiety when imagining the possible public-shame loss associated with being truthful, but he or she could not experience actual public-shaming for his action until after the truth came out!). All the same, it is quite likely that the wrongdoer, caught in a shame/guilt spiral, will feel deeply, deeply ashamed; both when contemplating his motivation for silence/deception and when trying to explain that silence after having been discovered.

The point is critical and therefore warrants an example: a man who has betrayed his wife through infidelity may feel authentic guilt and authentic shame; and these forces might incline him to confess and make reparation. He may, nevertheless, feel great anxiety regarding the possible shame-loss associated with telling his wife the truth, for the wife may take actions that diminish him in community or public space - she may tell his children; she may divorce him (effectively splitting his financial worth in half, and rendering him homeless and without a family); she may commit a counter-infidelity (as revenge); or she may alienate him from his friends. And, even if she does none of these things, the man may imagine that she will thereafter see him as lesser, something that he would rather avoid. Anxiety with respect to any of these shame-loss outcomes may forestall the man's tendency to tell the truth; and he may instead choose to carry the burden of spiraling authentic shame and authentic guilt (aggravating both these feelings) rather than face the burden of interpersonal or public shame and shame-loss, which he regards as greater and more devastating. Again, this is an example of what Aquinas means when he says that great moral failings are the result of disordered value (Aquinas, 1945: p. 686-687). ${ }^{34}$ Of course, it is quite likely that withholding the truth in this way and for these reasons will lead to other forms of betrayal and in this way a mountain of inauthenticity can be piled upon a single person over time, beginning with a single injustice. ${ }^{35}$ Such a person makes "reputation destiny; by degrading the inner self to second, third, or merely adventitious place, and making the social façade supreme, so that at every step the self will be sacrificed to the façade” (Henry, 1971: p. 10). In such a case, the individual faces an internal, ongoing struggle to cope with the escalating authentic shame and guilt that are specific to the violation of conscience (i.e., the shame-guilt spiral), and this will continue until the situation is otherwise resolved and brought to justice or until that time, "when this better self no longer exists (and) we have the blinding of moral vision (obcaecatio) and the hardening of moral responsibility (obduratio) which characterize what we call the dead conscience” (Turro, 1971: p. 18) for as Fulton Sheen says, one of the four ways to still a conscience is to kill it (Sheen, 1954: p. 91). ${ }^{36}$

It should also be mentioned that public shame may be indiscriminate (i.e., inauthentic) with respect to the goodness of the act it shames-its concern being the status-maintenance, status-enhancement, or status-loss associated with it. ${ }^{37}$ A poorly chosen outfit, a silly haircut, and a car with a dent can as easily lead to others bur-

\footnotetext{
${ }^{34}$ Or (Aquinas, ST, II-I, a. 1).

${ }^{35}$ Hence the eternal popularity of Sir Walter Scott's couplet, “Oh, what a tangled web we weave...when first we practice to deceive!” (Scott, 1883, p. 94)

${ }^{36}$ For an example of the dead conscience, see Lifton (1986: pp. 175-179). The author quotes doctors casually discussing practical problems associated with killing people in concentration camps. For, example, discussing disposal of the bodies, Dr. B. says, "Now that is a great problem, igniting piles of corpses. You can imagine—naked—nothing burns. How does one manage this?” (ibid, p. 177) Lifton's book is the great treatise on the dead conscience.

${ }^{37}$ Rudolph the red nosed reindeer was shamed in just this way.
} 
dening a person with shame, as can leaving one's children outside on a rainy day, shouting angrily at a coffee shop employee, or neglecting to supervise one's dog who leaves the yard and bites a neighbor's child. All six of these can bring public shame, because the injury felt in shame is the diminished value of the self. However, authentic guilt cannot be experienced with respect to one's outfits, haircuts, and the condition of one's car, though it can be experienced with respect to the children, the coffee shop worker, and the neighbor's child because, in the latter three cases, the injury mourned is the unjust injury to the other. The former cases then, though sources of anxiety, are not matters for conscience and do not threaten the authentic self. All the same, because of the power of public shame and the anxiety people have with respect to it, it is possible to commit an act that could lead to authentic guilt and shame in order to avoid a morbidly inauthentic public shame-for example, to punch another child in the nose under the provocation of other children in order to avoid being called a "chicken" for failing to do so. Lying to others about one's job status is an excellent example of this pathology. ${ }^{38}$

In all cases where authentic shame finds itself misaligned with public shame, the individual is likely to experience moral turbulence for failure to live up to his or her own conscience demands, so long as a living conscience continues to exist. And, as was the case with guilt, where shame cannot be redeemed, resoluteness must be taken up as the only remaining path to wholeness.

\section{Conscience and Reparation or Resoluteness}

As discussed earlier, conscience can be proactive-it can lead to a motivation to heal and help the world and others. When mindfulness and reflexivity have failed, however-in other words when the self has failed in the eyes of conscience, then conscience may call after the fact, as it does in shame and guilt. In these cases, conscience should not be regarded as an irrational punisher; a burden, as it is so often regarded. Rather, conscience calls for a repair to the self through a repair of one's world. In principle, the troubled or injured conscience is best repaired by repairing the damage that one has brought forth or allowed in the world. Then, having solved the problem of injustice, conscience will return one to a state of peace. Where repair is not possible, however, conscience will not rest easily; and in such cases, shame and guilt may persist for some time. However, in living with these feelings, one lives with one's truth, remains true to oneself in such a way that self-awareness is not lacking.

The exemplary case of a moral crime for which no cure was possible is the Eatherly story, discussed earlier. Neither the 'boon of punishment' nor the opportunities for repair were ever great enough to give the former pilot a sense of redemption, and there was no price he could pay (prison, loss of wife and children, loss of reputation, mental health incarceration) that would equal the 200,000 lives lost through an action for which he felt responsible and unforgivable. In some ways, the Eatherly case seems totally apart from us because of the issue of scale discussed so early in this paper. However, for current purposes, it illustrates nothing more than the general category of irreparable moral failure-those occasions when an injustice has been committed and nothing can be done to repair it. We all experience these sorts of events-in car accidents that leave a sense of guilt and shame for injuring others, in slanders spoken thoughtlessly that apology cannot erase, in the death or injury of people we care about through thoughtless and irresponsible actions of our own, in the anger we have shown that will not be forgiven, and in the betrayal of people that we love who afterward abandon us. And, should we experience such burdens of unreleasable guilt and shame, we also may find consolation in what Günther Anders wrote to the pilot, as did Eatherly, himself:

...the fact that you cannot master what is done is consoling because it shows that now, afterwards, you are making the attempt to realize the magnitude of your acts. Although the repentance cannot succeed, you must daily experience the frustration of your efforts. For outside of this experience of failure, there is nothing else which could replace the repentance. Better for you to try and fail—for when you fail, you are doing all that is

\footnotetext{
${ }^{38} \mathrm{An}$ acquaintance who had, for more than a year, been dating a doctoral student in (let us say) a Classics program in a major American university, visited the department in order to surprise him one day and asked the secretary for his office. The secretary had no knowledge of the student when asked for his office number, nor did any of the other administrative staff. It was determined, after looking through files that the young man had applied for graduate study five years before but had been rejected. Unable to face the public shame associated with this rejection, he told his friends that he had been accepted and began a lie that absorbed his entire life for five years, including relationships with new people such as the one he had with this woman. This story is now years old, and one can only assume that he has confessed to everyone he knows, or that he has packed up and moved off to another city to take an imaginary position in a Classics department somewhere else. His entire identity was, that is to say, taken over and falsified by an initial lie intended to avoid inauthentic public shame. Moreover, he was forced to suffer authentic shame with respect to every intimate relation he had because they were all premised on a fundamental lie.
} 
humanly possible, as you do by trying to go on as the one who has done it. Through this commitment to failed repentance, you have remained identical with your deed and have been changed by this deed. You, contrary to the others, have remained a human being, or have become one anew. (Anders \& Eatherly, 1989: p. 2-5 [abridged])

The maxim is simple: better to be authentically guilty, ashamed, and even (in some cases) agonized than to be inauthentically glorified or self-righteous, for this is living willingly within one's authentic situation - what is called resoluteness; living with one's destiny as it has unfolded through whatever given combination of fate and free will one lives amidst. Resoluteness is a disposition that applies, whether one has betrayed a romantic partner, killed a child in an automobile accident, or dropped a bomb on innocent civilians. Through it, one cleaves to who one is (whatever one is), perhaps prays for the possibility of growing back in the direction of what one was before, perhaps grows forward in relation to what one is now. And, sometimes, in the most fortunate of cases, one ultimately finds oneself released from the existential burden, and able to move on.

But this is no easy fix. There is no timetable for resoluteness and the common advice to just get over it can be absurd and possibly pathological, if it leads to forced recovery. Conscience releases the self in its own time, possibly never at all, and therefore requires the great virtues of patience and acceptance.

We cannot compel anyone to accept himself. But sometimes it happens that we receive the power to say "yes" to ourselves, that peace enters into us and makes us whole, that self-hate and self-contempt disappear, and that our self is reunited with itself (Tillich, 1987: p. 202).

In a rushed culture, such patience seems useless, but there is much to be learned from the state of resoluteness and remorse — one learns humility and, therefore, how to be a better person, even if never set free.

My conscience, since I know I've done a dreadful deed, like an ulcer in the flesh, leaves behind it in the soul regret which ever continues to wound and prick it. I lament that none is to blame for this but me myself, which is chanted over and over, making the pain even heavier by reason of the disgrace one feels (Plutarch, 1939: p. 476, F-477 [abridged]).

The ancient expression of Plutarch found herein-none is to blame for this but me myself-might first be said with a great inward horror. But this same expression can eventually transform into a consolation, and finally into a great healing. Both tragedy and comedy (i.e., all's well that ends well!) are part of human destiny. To deny either is to deny the fullness of time's maturing gift; and this is why holding to the self in both its accomplishments and its failures is the foundation of authentic being in the world. Few people wish for tragic life, of course. But tragedy, in its own way, is also deeply wondrous, beautiful. It also is a meaningful way to complete one's life.

\section{Conclusion: Conscience and the Creative Imagination}

There are, of course, many occasions when it is easy to satisfy conscience's demand. If a man drops a set of keys, for example, it is no great trouble to point this out to him. On the other hand, many are the occasions when it is much more challenging to satisfy conscience. Some moral challenges can be very complex; moreover, because they are existential problems, the consequences of failure are exponentially magnified. Revealing the truth to one person may bring harm to another, for example, giving one person what is deserved may cause another person to go without. Indeed, where conscience is exposed to a complex challenge, a solution may not be found in strength of character alone-on such occasions, the imagination of a creative person who is oriented toward inter-relational justice may play a critical role in satisfying the demands of conscience. Thus, creativity also finds itself a critical tool in the service of conscience and authentic selfhood.

But what is creativity? Arthur Koestler provides us an answer. For Koestler, creativity arises when a collection of ideas that are linked together in one single line of thinking (the $X$ axis) is intersected by a collection of ideas that are constrained by another line of thinking (the $Y$ axis), so that a relationship between the two previously separated realms is suddenly apparent. An example occurred in recent years when a boilerplate engineer, Tal Golesworthy, learned that his aortic artery lacked rigidity and needed to be replaced by an artificial one in a surgery that would require long hours, heart stoppage, significant risk, and long-term side-effects. Golesworthy did not like the prognosis, nor did the procedure seem necessary to him. To him, an engineer who designed boilers, the strengthening of a weakened pipe or hose was much more easily accomplished by giving it an external 
wrapping - he did it all the time. So Golesworthy took the idea of treating his aortic artery in the way he would treat a boiler pipe to his surgeons, and a new surgical technique was developed from it ${ }^{39}$ (Mashta, 2010). ${ }^{40}$

In cases such as the one above, serendipity is critically important in the creative process-one axis of ideas (the boilermaker's) coincidentally crosses paths with another axis of ideas (the surgeon's) in the real world and in real time. Then, on those occasions when a radical act of noticing occurs, a creative revolution may follow. Note, however, that this form of creativeness is heavily reliant on accidental circumstance and thus not always available at the moment it is needed. Only imagination elevates this sort of creativity from the fortuitous to the deliberate, when the imaginative person crosses one line of thinking with another in acts of deliberate and inadvertent imaginative activity, rather than relying on the happenstances of life (such as, in this case a boilermaker's need to have heart surgery) to trigger these associations.

Of course, the great example of this talent for creative imagination is the poet who represents the shades of experience by exploiting the various forms of metaphor (e.g., simile, metonymy, personification, synecdoche). Even the most banal of poets can write that his heart is "bursting with joy" without actually having to observe a person in the midst of a heart attack, for his or her imaginative power tracks the relationship between one axis (i.e., happiness) of experience and the other (i.e., explosions). And it is through such associations that many of the challenges of conscience can be satisfied as well.

The following is an illustration of this principle as it relates to the management of conscience: One of my students some years ago, wrote a final essay about her activities as a shoplifter. By her own description, it was somewhere in the midst of the ethics class, having come to acquaintance with a clearer recognition of who she believed she really was, that she found herself leaving a mall with another pair of jeans that she had pilfered from a store. It was a reflexive moment but also a moment of epiphany for her, when she realized that she already had five pairs of jeans and that the price she would pay for this pair was far greater than what they cost in dollars-that she was setting off in the direction of the "dead conscience". She, therefore, decided immediately that she would not keep the jeans (which had changed in their very appearance to her), and that she would never steal again. Nevertheless, she still faced a dilemma, because the authentic guilt and shame she experienced as taker of the jeans was in conflict with the anxiety of public shame and shame-loss she knew she would experience if she handed the jeans directly back to the proprietress. So it was through an imaginative act that she resolved the dilemma to her personal satisfaction. The student realized that her skills and experience as a thief dwelled along one axis of her life (the $X$ axis) while her need to satisfy conscience dwelled along another axis. She decided to allow the lines to cross, using her smuggling skills to put the jeans back in the location from which she had taken them, without detection. While her answer may not satisfy all of us in terms of its nobility, by her testimony, it satisfied her. It was the means by which she corrected the wrong that she had done that day and turned a new page in her life at the same time. And it was through her use of the creative imagination that she did so.

This is but an example. There are many others. An employer troubled about laying off an employee may call his supplier or other franchises in an effort to find stable alternative placement for the worker. A man incapable of repaying a debt in a timely way may offer to pay back the debt in installments or to offer services in lieu of cash. A woman who separated two friends by virtue of a misplaced word may find a way to bring the pair back together in a manner that resolves the issue. It is impossible, and ultimately absurd, to provide a list of creative solutions to moral problems because the function of creativity is to find a solution spontaneously in the midst of the crisis as it reveals itself. However, this being a special issue (Ethics Education) of the Creative Education journal, it is important enough to illustrate that creativity and ethics, though they each exist on their own axis of ideas, do share their own critical intersection point.

Northrop Frye, the celebrated Canadian critic, had much to write about imagination. One of his most critical insights was that the imagination is educated (Frye, 1963). By this he meant that a functional imagination was constrained by principles that limited its operation (as an English poet is constrained by his language and a mathematician is constrained by numbers). ${ }^{41}$ It is hoped that the ideas set forth with regard to conscience, in this

\footnotetext{
${ }^{39}$ Koestler (1964) himself illustrates the point with the famous water-displacement discovery made by Archimedes when he entered his bath.

${ }^{40}$ The same sort of discovery occurred for Archimedes, who needed (by virtue of sheer coincidence) to enter a bathtub (the $X$ axis) while thinking about complications associated with resolving a volume problem (the $Y$ axis) in order to discover the solution to an assignment his ruler had set for him.

${ }^{41}$ Frye (1970) also held that Imagination is concerned. He uses this term to distinguish imagination from the imaginary and from flights of fancy. As he characterizes imagination, the quality plays a fundamental role in the management of existence and participates meaningfully in the creation of our society. Guided by an existential "conviction that life is better than death, happiness better than misery, freedom better than bondage” (Frye, 1992: p. 21) imaginative vision is a force that drives human life toward its own improvement.
} 
essay, can serve as constraints for an "educated" framework through which students can take regard of their own ethical challenges and the creative living of the conscience-activated life.

Finally, I would like to point out that the word "student" comes from the word studiositas, a term which concerns itself with transformation and enlightenment through patient effort (Pieper, 1966: p. 198). Ultimately the term implies that we all are students if we choose to be; that all of us can experience educare (i.e., education), can be led out of darkness into illumination (Sproule, 2000: p. 35). Conscience, we have learned in this essay, can die (Turro, 1971: p. 18); but it may also live. For that to happen, for it to live, it must be brought into the light through examination and practice of the considerations and competencies set out in this essay. And, this is not only the task of the young. Therefore, let us all choose to be students of conscience, so that conscience may lead us back into the light.

A Native American Elder once described his own inner struggles in this manner: "Inside of me there are two dogs. One of the dogs is mean and evil. The other dog is good. The mean dog fights the good dog all the time." When asked which dog wins, he reflected for a moment and replied, "The one I feed the most." (Burstyn, 1997: p. 15)

\section{References}

Allers, R. (1931). The Psychology of Character. New York: Sheen and Ward.

Anders, G., \& Eatherly, C. (1989). Burning Conscience: The Case of the Hiroshima Pilot Claude Eatherly, Told in His Letters to Günther Anders. New York: Paragon House.

Anton, C. (2001). Selfhood and Authenticity. Albany, NY: State University of New York Press.

Aquinas, T. (1945). Basic Writings of St. Thomas Aquinas (Vol. 2). New York: Random House.

Arendt, H. (1971). Total Domination. In R. Smith (Ed.), Guilt: Man and Society (pp. 217-253). Garden City, NY: Anchor Books.

Arendt, H. (1978). The Life of the Mind: Willing. New York: Harcourt, Brace, Jovanovich.

Aristotle (1996). Nicomachean Ethics. In J. Barnes (Ed.), The Complete Works of Aristotle: The Revised Oxford Translation (pp. 1729-1867). Princeton, NJ: Princeton University Press.

Assagioli, R. (1973). The Act of Will. New York: The Viking Press.

Bellah, R. (2006). The Robert Bellah Reader. Durham: Duke University Press.

Bennett, W. J. (1993). The Book of Virtues: A Treasury of Moral Stories. New York: Simon \& Schuster.

Birmingham, W. (1971). The Roman Catholic Layman. In W. C. Bier (Ed.), Conscience: Its Freedoms and Limitations (pp. 286-293). New York: Fordham University Press.

Bishop, P. (1966). Religious Freedom. In W. M. Abbott (Ed.), The Documents of Vatican II (pp. 675-697). New York: The America Press.

Buber, M. (1971). Guilt and Guilt Feelings. In R. W. Smith (Ed.), Guilt: Man and Society (pp. 85-116). Garden City, NY: Anchor Books.

Burstyn, E. (1997). Experiencing the Soul: Before Birth, during Life, after Death. Carlsbad, CA: Hay House.

Carveth, D. (2013). The Still Small Voice: Psychoanalytic Reflections on Guilt and Conscience. London: Karnak Books Limited.

Cicero, M. T. (1841). The Political Works of Marcus Tullius Cicero. London: Edmund Spettigue.

Cunningham, W. C. (1971). Conscience and Civil Disobedience. In W. C. Bier (Ed.), Conscience: Its Freedoms and Limitations (pp. 201-211). New York: Fordham University Press.

DeMarco, D. (1996). The Heart of Virtue: Lessons from Life and Literature Illustrating the Beauty and Value of Moral Character. San Francisco, CA: Ignatius Press.

Depew, D. J. (1995). Humans and Other Political Animals in Aristotle’s “History of Animals”. Phronesis, 40, 156-181. http://dx.doi.org/10.1163/156852895321051937

Dolan, J. V. (1971). Conscience in the Catholic Theological Tradition. In W. C. Bier (Ed.), Conscience: Its Freedoms and Limitations (pp. 9-19). New York: Fordham University Press.

Eichmann, A. (1961). Eichmann Tells His Own Damning Story, Pt. 1. Life Magazine, 49, 19-25/101-112.

Frye, N. (1963). The Educated Imagination. Toronto: House of Anansi Press. 
Frye, N. (1970). Speculation and Concern. In N. Frye (Ed.), The Stubborn Structure (pp. 38-55). Ithaca, NY: Cornell University Press.

Frye, N. (1992). Words with Power: Being a Second Study of the Bible and Literature. San Diego, CA: Harcourt, Brace, Jovanovich Publishers.

Garfinkel, H. (1956). Conditions of Successful Degradation Ceremonies. American Journal of Sociology, 61, 420-424. http://dx.doi.org/10.1086/221800

Glenn Gray, J. (1971). The Ache of Guilt. In R. W. Smith (Ed.), Guilt: Man and Society (pp. 269-307). Garden City, NY: Anchor Books.

Grotstein, J. S. (1985). Splitting and Projective Identification. Northvale, NJ: Jason Aronson, Inc.

Heidegger, M. (1962). Being and Time. San Francisco, CA: Harper and Row Publishers.

Henry, J. (1971). Vulnerability in Education. In J. Henry (Ed.), Jules Henry on Education (pp. 9-24). New York: Random House.

Henry, J. (1973). Values: Guilt, Suffering, and Consequences. In J. Henry (Ed.), On Sham, Vulnerability and Other Forms of Self-Destruction (pp. 107-119). New York: Random House.

Hyde, M. (2001). The Call of Conscience. Columbia, SC: University of South Carolina Press.

Kenny, R. W. (2001). Toward a Better Death: Applying Burkean Principles of Symbolic Action to Interpret Family Adaptation to Karen Ann Quinlan's Coma. Health Communication, 13, 363-386. http://dx.doi.org/10.1207/S15327027HC1304 02

Kenny, R. W. (2002). Resituating Rhetoric, Philosophy, and Poetics through the Call of Conscience. Quarterly Journal of Speech, 88, 245-264. http://dx.doi.org/10.1080/00335630209384373

Kenny, R. W. (2003). The Phenomenology of the Disaster: Toward a Rhetoric of Tragedy. Rhetoric and Public Affairs, 6 , 657-686. http://dx.doi.org/10.1353/rap.2004.0011

Kenny, R. W. (2004). Truth as Metaphor: Imaginative Vision and the Ethos of Rhetoric. In M. Hyde (Ed.), The Ethos of Rhetoric (pp. 34-55). Columbia, SC: University of South Carolina Press.

Kierkegaard, S. (1978). The Sickness unto Death: Kierkegaard's Writings (Vol. 19). Princeton, NJ: Princeton University Press.

Kilpatrick, W. (1992). Why Johnny Can't Tell Right from Wrong: Moral Illiteracy and the Case for Character Education. New York: Simon and Schuster.

Koestler, A. (1964). Act of Creation. London: Hutchinson and Company.

Lifton, R. J. (1967). Death in Life: Survivors of Hiroshima. New York: Random House, Inc.

Lifton, R. J. (1986). The Nazi Doctors: Medical Killing and the Psychology of Genocide. New York: Harper Collins Publishers.

Little, D. (1971). A View of Conscience within the Protestant Theological Tradition. In W. C. Bier (Ed.), Conscience: Its Freedoms and Limitations (pp. 20-28). New York: Fordham University Press.

Mandelbaum, M. (1955). The Phenomenology of Moral Experience. Glencoe, IL: The Free Press.

Mashta, O. (2010). Engineer Who Designed His Own Lifesaving Heart-Repair Kit. Daily Mail (Online). http://www.dailymail.co.uk/health/article-1243723/Meet-engineer-designed-lifesaving-heart-repair-kit.html\#ixzz3vfJdNIrs

May, R. (1975). The Courage to Create. New York: WW Norton and Company.

May, R. (1999). Freedom and Destiny. New York: WW Norton and Company.

McCool, G. A. (1971). The Conscience of the Religious Subject. In W. C. Bier (Ed.), Conscience: Its Freedoms and Limitations (pp. 269-283). New York: Fordham University Press.

Milgram, S. (2009). Obedience to Authority. New York: Harper Collins Publishers.

Mittscherlich, A. (1963). Society without the Father: A Contribution to Social Psychology. New York: Harcourt, Brace and World, Inc.

Mittscherlich, A., \& Mittscherlich, M. (1975). The Inability to Mourn. New York: Grove Press, Inc.

Morsell, J. A. (1971). Conscience and the Civil-Rights Worker. In W. C. Bier (Ed.), Conscience: Its Freedoms and Limitations (pp. 234-239). New York: Fordham University Press.

Nietzsche, F. (1971). Human, All Too Human: A Book for Free Spirits. Cambridge, MA: Cambridge University Press.

Pells, R. H. (1998). Radical Visions and American Dreams: Culture and Social Thought in the Depression Years. New York: Harper and Row.

Philo (of Alexandria) (1937). Philo, Volume 7: On the Decalogue. Cambridge, MA: Harvard University Press. 
Plato (1963). Gorgias. In E. Hamilton, \& H. Cairns (Eds.), Plato: The Collected Dialogues. Princeton, NJ: Princeton University Press.

Plutarch, M. (1939). Moralia: On Tranquility of Mind. Cambridge, MA: Harvard University Press.

Pieper, J. (1966). Four Cardinal Virtues. Notre Dame, IN: University of Notre Dame Press.

Pieper, J. (1988). A Brief Reader on the Virtues of the Human Heart. San Francisco, CA: Ignatius Press.

Ratterman, P. H. (1971). Conscience and Student Protest. In W. C. Bier (Ed.), Conscience: Its Freedoms and Limitations (pp. 240-248). New York: Fordham University Press.

Russell, B. (1945). A History of Philosophy. New York: Simon \& Schuster.

Scheff, T. J. (1994). Microsociology: Discourse, Emotion and Social Structure. Chicago, IL: University of Chicago Press.

Scheler, M. (1973). Formalism in Ethics and Non-Formal Ethics of Values: A New Attempt toward the Foundation of an Ethical Personalism. Evanston, IL: Northwestern University Press.

Scott, W. (1883). Marmion: A Tale of Flodden Field. In W. Scott, \& J. W. Lake (Eds.), The Poetical Works of Walter Scott with the Sketch of His Life (pp. 53-99). Philadelphia, PA: Thomas Cowperthwait and Company.

Selznick, P. (1992). The Moral Commonwealth: Social Theory and the Promise of Community. Berkeley, CA: University of California Press.

Shakespeare, W. (1974). Richard III. In G. B. Evans (Ed.), The Riverside Shakespeare (pp. 708-765). Boston, MA: Houghton Mifflin Company.

Sheen, F. (1954). Peace of Soul. Garden City, NY: Doubleday.

Sproule, R. (2000). The Consequences of Ideas. Wheaton, IL: Crossway Books.

Taylor, C. (2003). The Ethics of Authenticity. Cambridge, MA: Harvard University Press.

Tillich, P. (1987). The Essential Tillich: An Anthology of the Writings of Paul Tillich. New York: Macmillan Publishing Company.

Todorov, T. (1996). Facing the Extreme: Moral Life in the Concentration Camps. New York: Henry Holt and Company, Inc.

Turner, J., \& Stets, J. (2005). The Sociology of Emotions. New York: Cambridge University Press. http://dx.doi.org/10.1017/CBO9780511819612

Turro, J. C. (1971). Conscience in the Bible. In W. C. Bier (Ed.), Conscience: Its Freedoms and Limitations (pp. 3-8). New York: Fordham University Press.

Voland, E. (2014). The Biological Evolution of Conscience-From Parent Offspring Conflict to Morality. Anthropological Review, 77, 251-271. http://dx.doi.org/10.2478/anre-2014-0020

Weisskopf, W. (1959). Comment. In P. Sorokin (Ed.), New Knowledge in Human Values. Chicago, IL: Henry Regnery Company.

Zahn, G. C. (1971). Conscience and the Soldier. In W. C. Bier (Ed.), Conscience: Its Freedoms and Limitations (pp. 212233). New York: Fordham University Press. 